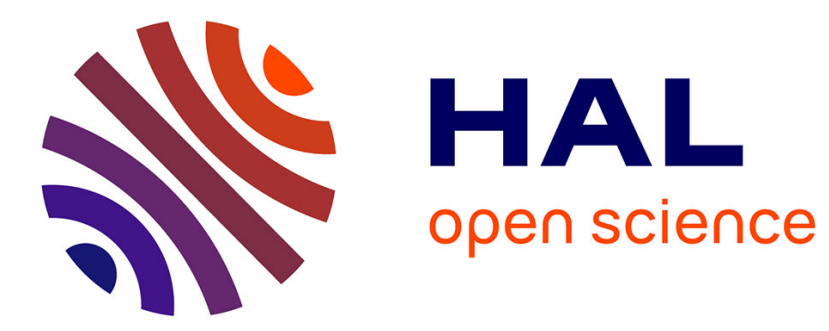

\title{
Plant hydraulic architecture through time: lessons and questions on the evolution of vascular systems
}

Anne-Laure Decombeix, Anais Boura, Alexandru Tomescu

\section{To cite this version:}

Anne-Laure Decombeix, Anais Boura, Alexandru Tomescu. Plant hydraulic architecture through time: lessons and questions on the evolution of vascular systems. IAWA Journal, 2019, pp.1-34. 10.1163/22941932-40190254 . hal-02271765

\section{HAL Id: hal-02271765 \\ https://hal.umontpellier.fr/hal-02271765}

Submitted on 12 Oct 2021

HAL is a multi-disciplinary open access archive for the deposit and dissemination of scientific research documents, whether they are published or not. The documents may come from teaching and research institutions in France or abroad, or from public or private research centers.
L'archive ouverte pluridisciplinaire HAL, est destinée au dépôt et à la diffusion de documents scientifiques de niveau recherche, publiés ou non, émanant des établissements d'enseignement et de recherche français ou étrangers, des laboratoires publics ou privés. 


\title{
Running title: Hydraulic architecture through time
}

\section{Plant hydraulic architecture through time: lessons and questions on the evolution of vascular systems}

\author{
Anne-Laure Decombeix ${ }^{1}$, Anaïs Boura ${ }^{2} \&$ Alexandru M.F. Tomescu ${ }^{3}$ \\ ${ }^{1} A M A P$, Université de Montpellier, CIRAD, CNRS, INRA, IRD, Montpellier, France \\ ${ }^{2}$ CR2P, Sorbonne Université, MNHN, CNRS, Paris, France \\ ${ }^{3}$ Department of Biological Sciences, Humboldt State University, Arcata, California 95521,
} USA

\begin{abstract}
Studies of anatomically preserved fossils provide a wealth of information on the evolution of plant vascular systems through time, from the oldest evidence of vascular plants more than 400 million years ago to the rise of the modern angiosperm-dominated flora. In reviewing the key contributions of the fossil record, we discuss knowledge gaps and major outstanding questions about the processes attending the evolution of vascular systems. The appearance and diversification of early vascular plants in the late Silurian-Devonian was accompanied by the evolution of different types of tracheids, which initially improved the hydraulics of conduction but had less of a mechanical support function. This was followed in the Devonian and Carboniferous by an increase in complexity of the organization of primary vascular tissues, with different types of steles evolving in response to mechanical, hydraulic, and developmental regulatory constraints. Concurrently, secondary vascular tissues, such as wood, produced by unifacial or bifacial cambia are documented in a wide array of plant
\end{abstract}


groups, including some that do not undergo secondary growth today. While wood production has traditionally been thought to have evolved independently in different lineages, accumulating evidence suggests that this taxonomic breadth reflects mosaic deployment of basic developmental mechanisms, some of which are derived by common ancestry. For most of vascular plant history, wood contained a single type of conducting element: tracheids (homoxyly). However, quantitative (e.g. diameter and length) and qualitative (e.g. pitting type) diversity of these tracheids allowed various taxa to cover a broad range of hydraulic properties. A second type of conducting elements vessels, is first documented in an extinct late Permian (c. $260 \mathrm{Ma}$ ) group. While the putative hydraulic advantages of vessels are still debated, wood characterized by presence of vessels (heteroxyly) would become the dominant type, following the diversification of angiosperms during the Cretaceous.

KEYWORDS: fossil; xylem; tracheids; vessels; Paleozoic; Mesozoic; wood; cambium.

\section{INTRODUCTION}

The term "hydraulic architecture" was first used in the title of a 1978 paper by Martin Zimmermann that compared water flow in different parts of trees with diffuse porous wood. Hydraulic architecture has since received several definitions (see Cruiziat et al. 2002 for a review), the simplest and most general of which defines it as "the structure of the water conducting system" (Tyree \& Ewers 1991). The functioning of plants as hydraulic systems has always intrigued botanists and the continued development of new techniques to assess and quantify xylem hydraulic properties has provided a wealth of data on the physical laws and structure-function relationships that control water flow in plants (McCulloh et al. 2003; Hacke et al. 2005; Sperry et al. 2006, 2008; Choat et al. 2008; Pittermann et al. 2011).

Understanding the anatomy of vascular tissues, the pipelines of the plant's hydraulic system 
(Cruiziat et al. 2002), remains an essential aspect of these studies (e.g., Pittermann et al. 2005, 2006a).

Among paleobotanists, the question of the evolution of vascular systems is almost as old as the first observations of fossil plants (e.g., Witham 1831, 1833; Unger 1847; Göppert \& Stenzel 1892; Renault 1879). Xylem, the water conducting tissue of vascular plants, typically contains cells with thickened secondary walls (tracheary elements, which are a type of sclerenchyma cells), usually lignified, which are resistant to degradation and, consequently, often well-preserved in the fossil record. The high preservation potential of xylem has underpinned the discovery of major steps in the evolution of vascular tissues, which can be traced back to the appearance of the first vascular plants more than 400 million years ago. The continued discovery of new fossils, combined with the development of new observational techniques and mathematical models, allow access to a steady flow of novel information on the hydraulic architecture of extinct plants, some of which have no living equivalent or were growing in very different environmental conditions (e.g., in terms of climate or atmospheric $\mathrm{CO}_{2}$ levels). In this review, we summarize the state of the art and main developments in studies of the evolution of vascular systems based on the fossil record, and outline some outstanding questions about the processes that led to the appearance of plant structures that we observe today.

\section{THE FIRST VASCULAR PLANTS}

Vascular plants, also known as tracheophytes (Kenrick \& Crane 1997; Fig. 1), largely dominate modern terrestrial ecosystems, where they represent over 380000 species (Willis 2017). Tracheophytes are characterized by the possession of specialized water-conducting cells (tracheary elements) that are longitudinally elongated, non-living at maturity, and have a secondary cell wall laid down in different thickening patterns: annular, helical, scalariform, 
and reticulate or pitted. Pits are cell wall areas without secondary wall (i.e., holes in the permeable membrane formed by the primary wall and middle lamella.

Microscopic tubes with internal thickenings found in early Silurian to Early Devonian (c. 440-410 Ma) deposits were initially interpreted as fossil tracheids (Martin 1971). However, the wall ultrastructure of these banded tubes is distinctly different from that of vascular plant tracheary elements (tracheids and vessels) and their role, as well as the organisms they belonged to, remain highly conjectural (Gray \& Boucot 1977; Taylor \& Wellman 2009). The oldest unequivocal tracheids are a little younger, dating back to the late Silurian-Early Devonian, a little over 400 million years ago (Edwards \& Davies 1976). Early Devonian coalified fragments of Cooksonia (Paratracheophyta) possess a central strand composed of a few tracheids that are 2-11 $\mu \mathrm{m}$ in diameter (Lang 1937; Edwards et al. 1992). Because Cooksonia is first recorded in the Silurian (Fig. 2), and tracheids have also been reported from late Silurian sterile axes in a fossil assemblage containing Cooksonia-type sporangia (Edwards \& Davies 1976), Cooksonia is traditionally regarded as the oldest vascular plant. However, the anatomy of Silurian Cooksonia specimens is unknown and since recent analyses show that the various species of the genus do not form a monophyletic group (Gonez \& Gerrienne 2010), the vascular plant status of the oldest Cooksonia remains equivocal.

Investigations of early tracheids with scanning electron microscopy, starting in the 1990s, have led to the recognition of several types that are based on the structure of their wall thickenings (Kenrick \& Crane 1991; Friedman \& Cook 2000; Edwards 2003; Fig. 3). S-type tracheids have large and simple annular or helical thickenings. The spongy material of the wall thickenings is covered on the lumen side by a thin decay-resistant microporate layer (Kenrick \& Crane 1997; Fig. 3B). S-type tracheids, named after the first fossil plant in which 
they were described, Sennicaulis (Paratracheophyta, Fig. 1), are also found in a few other fossil plants of Early and Middle Devonian age (Pfeiler \& Tomescu 2018). The G-type tracheid, exemplified by the fossil plant Gosslingia (Zosterophyllales, Fig. 1), has annular or helical thickenings that can take a scalariform or reticulate aspect through the development of connections between horizontal thickenings. The cell wall between thickenings bears multiple minute perforations (Fig. 3C). G-type tracheids are found in some early representatives of the lycopsids and their extinct precursors, the zosterophylls. Tracheids of the P-type, exemplified by Psilophyton (Trimerophyta, Fig. 1), have bordered pits that are scalariform, more rarely almost circular (Edwards 2003). Unlike the bordered pits found in the tracheids of extant plants, their relatively large apertures are covered by a characteristic perforate membrane made of secondary wall material (Fig. 3D). This peculiarity is found in basal members of the euphyllophytes (Kenrick \& Crane 1997; Strullu-Derrien et al. 2014; Bickner \& Tomescu this issue, Fig. 1), the clade that comprises all living non-lycopsid tracheophytes and their extinct relatives, also known as Trimerophyta. The tracheids of some fossil and extant lycopsids also possess a perforated membrane or fimbrils ("Williamson's striations") across the scalariform pit aperture (Cichan et al. 1981), but it is unknown whether these structures are homologous to the ones observed in early euphyllophytes (Edwards 2003). Interestingly, some Devonian taxa show a combination of different types of tracheids within a single plant. This is the case for example in an unnamed fossil from the Early Devonian of Norway in which the main axis has G-type tracheids, while the tracheids of lateral branches possess circular to scalariform or reticulate bordered pits (Edwards et al. 2006).

Some of the most emblematic representatives of early vascular plants were found silicified in hydrothermal cherts from the Rhynie area in Aberdeenshire, Scotland (midPragian-?earliest Emsian; Edwards et al. 2017). While these cherts preserve the vegetation of unusual environments (volcanic hot springs) (Wellman 2018), they have yielded some of the 
best anatomically preserved fossil plants from the Early Devonian interval. Among them, Aglaophyton (Protracheophyta), Rhynia (Paratracheophyta), Asteroxylon (Drepanophycales), and Horneophyton (Horneophyta) are all small plants $(<20 \mathrm{~cm}$ tall) that lack leaves and true roots and illustrate different stages in the evolution of vascular systems. In Aglaophyton, the water conducting cells lack wall thickenings of the kind typically seen in tracheids. Because these cells have a structure intermediate between true tracheids and the hydroids found in bryophytes, Aglaophyton is considered a protracheophyte, not a true vascular plant. Rhynia, on the other hand, possesses true tracheids with annular to helical thickenings (S-type). The tracheids of Asteroxylon are of the G-type. Analyses of fossil cell wall chemistry by Boyce et al. (2003) have shown that the tracheids of Rhynia were likely unlignified, whereas those of Asteroxylon were heavily lignified. A fourth plant found in the Rhynie chert, Horneophyton, was regarded as another protracheophyte, but recently Cascales-Miñana et al. (2019) documented cells with irregular, annular to helical wall thickenings of putative secondary origin. They interpreted these cells as representing a new intermediate, this time between the simple cells without secondary thickenings found in protracheophytes, such as Aglaophyton, and the true tracheids found in Rhynia or Asteroxylon.

Biomechanical studies by Speck and Vogellehner $(1988,1992)$ showed that the tracheids of the first vascular plants did not contribute much to the flexural stiffness of axes, of which $>80-90 \%$ could be attributed to either turgor pressure in the parenchymatous cortex, or to a sclerified hypodermal sterome. The observed increase in the complexity and strength of tracheid secondary wall thickenings is, thus, likely linked to maintenance of their water conducting properties, i.e., improved resistance to inward collapse and cavitation (Carlquist 1975; Hacke et al. 2001), in correlation with the trend of increasing tracheid diameters for increased water conductivity that was documented for the Devonian (Niklas 1994). Thus, a first important lesson from the fossil record is that the early evolution of vascular tissues was 
in all likelihood not under the constraint of a compromise between hydraulic and mechanical

A significant time interval separates the oldest fossil evidence of land plants (Fig. 1), represented by middle Ordovician spores (Rubinstein et al. 2010), and the diversification of vascular plants in the Early Devonian. However, it is important to note that the oldest evidence for plants with vascular tissue consists of late Silurian macrofossils (Kotik et al. 2002; Libertin et al. 2018) and possibly of hilate/trilete spores of early Silurian age (Gray \& Boucot 1977; Steemans et al. 2009). The age disparity between these different types of fossils may be a reflection of different biases in taphonomy, geographic sampling, or the nature of the rock record, with respect to different plant parts and fragments. Vascular tissues are known to be quite resistant to degradation, thus, early vascular plants are expected to be better preserved than other types of plants. Kenrick et al. (2012) argue that the paucity of their remains before the late Silurian-Early Devonian could be due to biases, including (1) the poor prospection of the supercontinent Gondwana, which corresponded to today's southern continents and where land colonization by plants might have started (Steemans et al. 2009), and (2) the paucity of terrestrial deposits that pre-date the latest Silurian and that are exposed today, especially those representing fluvial or lacustrine depositional environments in which most early vascular plant remains are typically found. Until these potential biases are better understood and addressed, the tempo of evolution of plant vascular tissues following the initial colonization of land and the possible underlying processes cannot be assessed with confidence. The most recent timescale of plant evolution using fossil calibrations and genetic data (Morris et al. 2018) proposes a middle Cambrian to Early Ordovician age for crown embryophytes and a Late Ordovician to Silurian age for crown tracheophytes. 
During the Devonian, major innovations, such as the appearance of leaves (Sanders et al. 2009; Langdale \& Harrison 2008; Tomescu 2009; Galtier 2010), the evolution of root systems (Boyce 2005; Hetherington \& Dolan 2018), or the appearance of pseudomonopodial branching - with morphological differentiation of a main axis and subordinate lateral branches (Gensel et al. 2001), led to an increase in complexity of plant architecture (Chomicki et al. 2017; Bonacorsi \& Leslie 2019; Crepet \& Niklas 2019). This was paralleled by an increase in complexity of the organization of the primary vascular tissues and the appearance of new types of steles (Figs.4-5). The stele of an axis includes the tissues derived from the procambium. In terms of mature tissues, this translates into vascular tissues (xylem and phloem) and associated ground tissues (such as the pericycle, leaf gaps, interfascicular areas) these issues are discussed in detail in an upcoming paper by Tomescu (work in progress).

In the most simple type of stele, the protostele, there is no pith and vascular tissues form a central strand. This type of stele, present throughout the entire geologic time scale of tracheophytes, occurs today in some taxa such as Lycopodium (Lycopodiales), Psilotum (Psilotidae), or Gleichenia (Glecheniales). A protostele is also the vascular organization found in the vast majority of roots, independently of their systematic affinities (Esau 1965; Beck 2005). The oldest type of protostele, the haplostele, has circular to elliptical shape in crosssection, with the xylem located in the center (Fig.4A-C). This architecture is typical of the earliest vascular plants (Kenrick \& Crane 1997; Fig. 2). Another type of protostele that became common in the Middle Devonian is the actinostele, in which the xylem has a lobed or star-shaped structure in cross-section (Figs.4D-F). Actinosteles are found in many Middle and Late Devonian taxa, including lycopsids, cladoxylopsids (i.e., Iridopteridales and Pseudosporochnales, Fig. 1), progymnosperms, Stenokoleales, and the first spermatophytes (Scheckler 1974, 1976; Beck \& Stein 1993; Rothwell \& Serbet 1994; Momont et al. 2016; Toledo et al. 2018; Fig.4F). 
The development of a central pith led to a new major type of stele, in which the

vascular tissues form a hollow cylinder (with pith at the center), the siphonostele (Beck et al. 1982; Stewart and Rothwell 1993). The vascular cylinder can be interrupted by leaf gaps where vascular traces diverge toward the leaves (Fig.4J-L). Various types of siphonosteles are present from the Late Carboniferous on, especially among the filicopsids (e.g., Phillips 1974; Beck et al. 1982; Rothwell 1999; Schneider et al. 2002). Late Devonian and Carboniferous lycopsid trees such as Sublepidodendron and Paralycopodites have vascular tissues arranged in a hollow cylinder in the largest part of their stems (Eggert 1961), but they lack leaf gaps and the question of whether these represent true siphonosteles is still debated. A variation of the siphonostele is the dictyostele, in which leaf gaps are long (tall) and overlap vertically, giving the impression of a dissected vascular system (Fig.5A-C). The oldest dictyosteles date from the Carboniferous, as seen for example in the marattialean tree fern Psaronius (Delevoryas 1964; Fig.5C). Today they are found in many ferns, such as Osmunda (Osmundales, Fig. 1) or the tree fern Dicksonia (Cyatheales) (Bower 1926).

In the eustele, which is typically found in spermatophytes, the vascular tissues are organized as discrete longitudinal sympodia around the pith (Fig.5D-F). The oldest example of this type of organization is seen in the Middle Devonian progymnosperm Archaeopteris (Scheckler 1978; Beck 1979; Fig.5F). Eusteles become more common following the diversification of seed plants in the Carboniferous, a period during which they are found in Cordaitales, early conifers (Voltziales), and various families of pteridosperms. Today, eusteles featuring more or less complex connections between the xylem of the stem and that of branches and leaves (Namboodiri \& Beck 1968; Beck et al. 1982) characterize the gymnosperms and angiosperms. Some monocotyledons have a modified eustele in which the sympodia are arranged in multiple concentric cycles (Beck et al. 1982). These multiple sympodia, in combination with the multiple leaf traces diverging from them, produce the 
impression of vascular bundles scattered randomly throughout the ground tissue and preclude first documented in fossil palm trunks (Palmoxylon; Fig.5I) from the Late Cretaceous (Santonian-Campanian, and possibly as old as the Turonian; Crié 1892; Berry 1916).

Several Middle Devonian to Early Carboniferous plants assigned to the extinct group of the cladoxylopsids displayed a vascular system with numerous separate xylem strands of various size and shape in transverse section. The number of strands ranges from a few in some specimens of Xenocladia (Pseudosporochnales) (Arnold 1952; Fig.4I) or Cladoxylon (Pseudosporochnales) (Bertrand 1935) to over 130 in the Late Devonian tree Xinicaulis (Cladoxylopsid) (Xu et al. 2017). Stewart and Rothwell (1993) interpreted this organisation as a transition from an actinostele to a plectostele, a type of protostele in which the xylem and phloem are arranged in alternating plates or U or V-shaped bands (in cross section) (Fig.4GI); in the most extreme cases, the central strands are absent and the architecture resembles that of a eustele.

While the diversity of stelar anatomy and the evolutionary pathways that led from one type of stele to another have been the subject of many hypotheses and discussions, very little is certain regarding the processes driving the diversification of stelar organization in the Devonian and thereafter. Different scenarios involving several categories of factors have been considered.

(1) Increasing mechanical demands. Walter Zimmerman was one of the first proponents of this mechanical hypothesis (Zimmermann 1959). Because the most peripheral tissues of the axis are the ones that have the highest impact on resistance to bending forces, the arrangement of the xylem at the periphery of a pith vs. at the center of the axis provides more stiffness (Speck \& Vogellehner 1988). This suggests that the evolution of stelar organizations that 
include a pith may have been driven, at least in part, by mechanical constraints associated with increase in size.

(2) Increasing demand of fluid transport. F.O. Bower proposed in 1908 the hypothesis that the stele increased in complexity in order to optimize water transport in plants that were evolving larger sizes and more complex organization (Bower 1908). The development of a central pith and peripheral xylem minimizes the distances between the water conducting cells and other tissues while limiting the amount of energy spent on producing expensive xylem cells (Raven 1994; Roth \& Mossbruger 1996). Thus, such hydraulic demands may have represented a different type of driver in the evolution of the pith.

(3) Changes in hormonal signals linked to the evolution of lateral organs. Building on earlier ideas formulated by Wight (1987), Stein (1993) modelled how the evolution of stelar architecture can be linked to the gradients of auxin produced by more complex lateral appendages (branches, leaves). Stein's models support an origin of pith at the center of the stele related to changes in shoot apex geometry under different hormonal gradient regimes, and the dissection of the stele into discrete vascular bundles as a result of changing receptivity to hormonal signaling.

In all likelihood, combinations of these different factors, which are not mutually exclusive, were responsible for stelar evolution in different groups, especially since the increase in complexity of lateral organs has a direct impact on the biomechanical and hydraulic demands of the plant, in addition to driving shifts in hormonal signaling patterns and homeostasis. It is also possible that these factors had different relative importance in shaping the vascular systems of different plant lineages. Leaves evolved independently in the two major tracheophyte groups - the lycopsids and euphyllophytes - and then, again, independently in several euphyllophyte groups (Tomescu 2009; Sanders et al. 2009; Galtier 2010). Given their independent origins, as well as differences in their developmental, 
anatomical, and physiological relationships with subtending stems, specific to each lineage,

the advent of leaves must have had different impacts on the architecture of the vascular system in each of these lineages. Nevertheless, the evolution of leaves, along with that of roots (also thought to have evolved independently, at least between the lycopsids and euphyllophytes; Boyce 2005; Hetherington \& Dolan 2018), and with the general increase in plant size, led to increasingly more complex plant architectures. These are all factors that can be linked to the increase in complexity of the architecture of the primary vascular system.

\section{VASCULAR CAMBIA AND SECONDARY GROWTH}

Another major event in plant evolution that occurred during the Devonian is the advent of the vascular cambium, a lateral meristem producing secondary vascular tissues. Two types can be distinguished: unifacial cambium, producing only secondary xylem (wood), and bifacial cambium that produces secondary xylem on one side and secondary phloem on the other side. Like other meristems, the vascular cambium can have permanent activity, leading to indeterminate growth, or can cease functioning at a genetically determined point, leading to determinate growth. Today, all plants with secondary vascular tissue - with the possible exception of the lycopsid Isoetes (Isoetales; Fig.6A-B)- are seed plants and have a bifacial cambium with indeterminate growth. In Isoetes, a cambial layer (the lateral meristem) produces a "prismatic layer" (consisting of tracheids and sieve cells) toward the inside and a thin layer of parenchymatous tissue toward the outside (Paolillo 1963; Gifford \& Foster 1989). Although functionally bifacial, this cambial layer produces vascular tissues only on one of its sides, like the unifacial cambia. Compared to the dearth of lineages exhibiting vascular cambial growth in the modern flora, the fossil record reveals a much broader diversity of modes of secondary growth (Tomescu \& Groover 2019; Fig.6). 
To date, the oldest known occurrences of secondary xylem are known from the Early

Devonian euphyllophytes Armoricaphyton (Strullu-Derrien et al. 2014; Gerrienne and Gensel 2016) from France and Franhueberia gerriennei (Hoffman \& Tomescu 2013) (Fig. 2) from Gaspé (Canada), and from a few additional, as yet unnamed, plant types from New Brunswick and Quebec (Canada) (Gerrienne et al. 2011; Gensel 2018). Subsequent to these early examples, the fossil record has revealed a remarkable diversity of geologically younger (Middle Devonian and early Carboniferous) plants that produced secondary xylem. This structural feature has been reported in lycopsids, basal euphyllophytes, cladoxylopsids, sphenopsids, basal filicopsids such as the zygopterids, stenokoleales, and lignophytes (Figs. 1, 2, 6). Thus, two key lessons are that (1) secondary growth evolved early (possibly earlier than $410 \mathrm{Ma}$ ago) and that (2) the occurrence of secondary xylem in vascular plants is quite common, even in groups that do not produce wood today, like the lycopsids and sphenopsids.

Lycopsids, basal euphyllophytes, cladoxylopsids, basal filicopsids, and sphenopsids are all interpreted as having a unifacial cambium (Cichan \& Taylor 1990; Fig.6A-E ). This type of cambium usually produced a small amount of wood (a few millimeters to a few centimeters) and no secondary phloem, but there are examples of Permian sphenopsids in which the wood cylinder exceeded $30 \mathrm{~cm}$ in radial thickness (Rößler \& Noll 2006). The bifacial cambium, producing both secondary xylem and secondary phloem, is considered the synapomorphy of the lignophyte clade, which includes the spermatophyte plants and their extinct progymnosperm sister group (Crane 1985; Doyle \& Donoghue 1986; Rothwell \& Serbet 1994; Fig. 6G-H). The oldest evidence for this type of cambium dates to the Middle Devonian, in the aneurophytalean progymnosperms Tetraxylopteris, Triloboxylon, and Proteokalon, all of which possess a well preserved complement of secondary phloem in addition to secondary xylem (Beck 1957; Scheckler \& Banks 1971; Stein \& Beck 1983; Fig. 2; Fig. 6G). The Stenokoleales, a Late Devonian-Early Carboniferous group of plants 
sometimes associated with the lignophytes (Matten 1992; Toledo et al. 2018), have some for secondary phloem, which would indicate the presence of a bifacial cambium in that group. Interestingly, a bifacial cambium is also documented in the Sphenophyllales, an extinct group of sphenopsids from the Late Devonian-Triassic (Taylor et al. 2009; Fig. 2). However, unlike that of the lignophytes, their cambium is usually interpreted as having determinate growth and the largest axes of the best known genus, Sphenophyllum, are only up to about $1 \mathrm{~cm}$ in diameter. Late Carboniferous and Permian representatives of Sphenophyllum had wood with a peculiar system of vertical parenchyma cells located at the corners of tracheids and connected to the rays that has no equivalent in other fossil or extant taxa (Cichan \& Taylor 1982; Cichan 1985; Fig. 6F). However, older representatives of the Sphenophyllales seem to have possessed a more typical wood anatomy (Terreaux de Felice $e t$ al. in press).

Among extant plants, the bifacial vascular cambium can show important variations in functioning, which lead to the development of secondary tissue configurations designated as cambial variants (e.g., Angyalossy et al. 2012; Pace et al. 2018a, b). Evidence for these different types of "anomalous secondary growth" has also been documented in the fossil record (reviewed by Bodnar \& Coturel 2012). For example, some members of the Corystospermales, an extinct group of spermatophytes from the Triassic (250-200 Ma), exhibit both centripetal and centrifugal wood development, as well as possible included phloem (Artabe \& Brea 2003; Decombeix et al. 2014).

As in the case of the first tracheids, the initial role of wood seems to have been hydraulic rather than structural (Gerrienne et al. 2011), and the wood of DevonianCarboniferous plants already exhibited hydraulic properties comparable to those of some modern taxa (Cichan 1986; Wilson et al. 2008; Cascales-Miñana et al. 2019, this issue; Tanrattana et al. 2019, this issue). A role in mechanical support was acquired later and only in 
certain groups (e.g., Rowe \& Speck 2004). Today, most trees are gymnosperms or support. However, several plant types, such as palms (monocotyledons) and tree ferns, demonstrate that secondary xylem is not needed to reach arborescence (i.e., the tree habit). Similarly, there are fossil examples of arborescent plants with no secondary xylem or in which the secondary xylem did not contribute much to the stiffness of the stem (Mosbrugger 1990; Meyer-Berthaud \& Decombeix 2009). Such is the case of the arborescent lycopsids, like the famous Lepidodendron (and related species of Lepidodendrales) of the Carboniferous, in which most of the mechanical support function was filled by a well-developed bark of secondary origin. The small central ring of wood, while very efficient for water conduction (Cichan 1986), played no role in the stem's stiffness (Mosbrugger 1990).

One of the major questions that remains regarding the evolution of secondary xylem is whether vascular cambial growth evolved independently in several tracheophyte lineages or only once, at the base of the clade (Tomescu \& Groover 2019). The traditional view, based on records of representatives with secondary growth in multiple lineages that could be traced back to the Middle Devonian (Fig. 2), was that there had been multiple independent evolutionary origins of this important developmental and structural feature. This perspective found support in the more-or-less major perceived differences in the anatomy of secondary tissues between the different lineages.

These traditional views are being reshaped by evidence coming from two directions. One of these is the realization that some mechanisms regulating vascular cambial growth are shared among major tracheophyte lineages spanning both the lycopsids and the euphyllophytes: lepidodendrales, sphenopsids, progymnosperms, and spermatophytes (Rothwell et al. 2008; Sanders et al. 2011). The other line of evidence is provided by the discovery of multiple euphyllophyte types that demonstrate secondary xylem production in 
the Early Devonian (Gerrienne et al. 2011; Hoffman \& Tomescu 2013; Strullu-Derrien et al. 2014; Gensel 2018). These fossils are pushing the documented occurrence of this feature to within a few million-years from the oldest representatives (and, potentially, the origin) of the clade. These data prompted Hoffman and Tomescu (2013) to propose that underlying mechanisms for secondary growth had become part of the euphyllophyte developmental toolkit very early in the evolution of the clade, and to raise the question of whether some of these mechanisms may have originated even earlier, in a common ancestor of euphyllophytes and lycopsids.

To provide an empirical framework for addressing such questions, Tomescu and Groover (2019) proposed an updated perspective that approaches vascular cambial growth as a complex developmental process of modular nature. Their view explains the diverse anatomies of secondary growth seen in different lineages (referred to as modes of secondary growth) as a mosaic pattern of expression of distinct developmental-regulatory modules (responsible for different component processes of secondary growth) among different lineages, living and extinct. This view emphasizes patterns of shared processes and developmental regulation, and accommodates a hypothesis-testing approach to address questions about the evolutionary origins of secondary growth.

\section{FURTHER EVOLUTION OF HOMOXYLOUS WOODS IN SEED PLANTS (SPERMATOPHYTES)}

From its first appearance in the basal euphyllophytes, through the lignophytes and all the way to the extant conifers, wood has fulfilled both its functions - conduction and mechanical support - with only one type of cell, the tracheid. The structure of wood that has only tracheids as conducting cells is referred to as homoxylous (Fig. 7). For example, in most conifers the tracheids have a small diameter $(<50 \mu \mathrm{m})$ and the rays are small - short and 
uniseriate. Wood of this type is known as picnoxylic (Fig. 7A). In contrast, extant cycads, as with diameters up to $150 \mu \mathrm{m}$ and large rays (more than 5 cells wide and up to 200 cells tall) (Galtier 1992; (Fig. 7B-C).

The first spermatophytes that appeared in the Late Devonian are represented by small axes with only a small amount of wood (Serbet \& Rothwell 1992), but significant patterns of anatomical disparity can be observed in the wood of homoxylous spermatophytes as soon as the early Carboniferous. For example, ray size in early Carboniferous spermatophytes ranged from uniseriate rays only one or two cells high in some taxa (such as like Bilignea) to multiseriate rays up to a hundred cells high in Calamopitys or Pitus (Galtier 1992; Galtier \& Meyer-Berthaud 2006; Dunn 2006; Fig.7B-C). A combination of very large rays and small tracheids $(<50 \mu \mathrm{m}$ in diameter) occurs in several early Carboniferous taxa, but is extremely rare in the rest of the fossil record prior to the appearance of vesselless angiosperms, toward the end of the Mesozoic (Philippe et al. 2010; Boura et al. 2019, this issue). Ray tracheids and axial parenchyma are present since at least the Late Devonian-early Carboniferous (Beck \& Wight 1988; Galtier \& Meyer-Berthaud 2006) (Fig. 7A).

Secondary xylem tracheids range widely between 15 and $97 \mu \mathrm{m}$ in diameter in Elkinsia, one of the best known Late Devonian spermatophytes (Serbet \& Rothwell 1992). In the Carboniferous and Permian, taxa with tangential tracheid diameters exceeding $100 \mu \mathrm{m}$ are found among several groups of pteridosperms, including the Calamopityales, Lyginopteridales, and Medullosales, while the Cordaitales, the first conifers, and other spermatophytes such as the Glossopteridales, had smaller tracheids (Cichan 1986; Pigg \& Taylor 1993; Vozenin-Serra et al. 1991). Tracheid length is less well documented, in part because the longest tracheids exceed the size of thin-section slides that have been prepared from fossil material. Tracheid length reaches at least $1 \mathrm{~cm}$ in Callistophyton 
(Callistophytales), and several centimeters in Medullosa, both of which are late Carboniferous spermatophytes.

Reconstructions of the hydraulic properties of selected fossil plants by Cichan (1986) and Wilson \& Knoll (2010) suggest that the wide, long, and densely pitted tracheids of the Carboniferous pteridosperms Medullosa, Callistophyton, and Lyginopteris occupied an area of tracheid morphospace that is not populated by any younger or extant seed plant taxa. Those authors hypothesized that the unusually high conductivity of these tracheids was related to the combination of a non-selfsupporting growth habit, in which tracheids do not play a role in mechanical support, and growth in a warm wetland environment in which there is little risk of embolism (air bubbles in the vascular system) caused by drought or frost. It is interesting to note that such high-conductivity tracheids are to date unknown in the Mesozoic pteridosperms, despite the existence at that time of broadly similar conditions.

The pitting of secondary xylem tracheids in the earliest spermatophytes typically consists of crowded multiseriate oval to oblique pits with oval aperture (Serbet \& Rothwell 1992), similar to most representatives of their sister group, the progymnosperms (Beck \& Wight 1988; Fig. 7D). A different type of pitting, with uniseriate circular pits possessing circular apertures, is documented in three Late Devonian-early Carboniferous woods belonging to progymnosperms or spermatophytes (Beck \& Wight 1988; Prestianni et al. 2010; Decombeix et al. 2011). Scalariform pits in secondary xylem tracheids are first documented in progymnosperms, such as Rellimia and Protopitys (Beck \& Wight 1988; Fig. 7E), and occur afterwards throughout the history of spermatophytes, for example, in the putative Permian conifer Xuanweioxylon scalariforme (He et al. 2013), and some cycads, bennettitales, and angiosperms, as well as in some Mesozoic taxa of uncertain affinities, such as Sahnioxylon or Ecpagloxylon (Philippe et al. 2010). Wilson \& Knoll (2010) hypothesized that the tracheids with scalariform pitting of the Cretaceous bennettitale Cycadeoidea had pit 
area resistances similar to those of extant vesselless angiosperms, such as Trochodendron, but pitting have yet to be properly understood.

One of the major events in the evolution of homoxylous woods was the advent of torus-margo pit membranes with a highly permeable water-porous marginal region, the margo, and a thickened central zone impermeable to water, the torus. Under normal and favorable conditions, water moves from one tracheid to the adjacent one through the margo while the torus is centrally located in the pit chamber allowing water flow. In the case of an embolism, the pit membrane is aspirated against the pit border, such that the torus blocks the pit aperture, preventing the spread of air through the xylem (Bailey 1916). Torus-margo pit membranes ensure, thus, both a high efficiency of water conduction when environmental conditions are hydraulically safe, and a high degree of hydraulic safety when conditions are degraded (Pittermann et al. 2005, 2006b; Sperry et al. 2006).

Today, torus-margo pit membranes are found in all extant conifer families (Bauch $e t$ al. 1972; Dute 2015), as well as in other gymnosperm taxa, such as extant Ginkgo (Wilson \& Knoll 2010) or the gnetales (Ephedra, Gnetum and Welwitschia) (Carlquist 2012), but are absent in the cycads (Bauch et al. 1972). Torus-margo pit membranes have also been reported in the fern genus Botrychium (Ophioglossidae) (Morrow \& Dute 1998). Most angiosperms lack a torus and have homogeneous membranes with smaller size pores randomly distributed. However, in a few angiosperm families (Ericaceae, Oleaceae, Thymeleaceae, Rosaceae, Ulmaceae, Cannabaceae, Schisandraceae), the fine mesh of the typical intervascular pit membrane is associated with a centrally thickened area that resembles a torus (Ohtani \& Ishida 1978; Ohtani 1983; Wheeler 1983; Jansen et al. 2004; Dute 2015; Nguyen et al. 2017). In 1967, Schmid pointed out that because of the small number of records of torusmargo pit membranes in the fossil record, the evolution of this character has been inferred 
largely based on data from living plants. Fifty years later this is still the case (Pittermann et al.

2010; Wilson \& Knoll 2010; Wilson 2016) and the timing of the evolution of torus-margo pit membranes remains an enigma. It is possible that this character evolved independently in different lineages, in response to environmental pressures, contributing to the optimization of the balance between safety and efficiency of the secondary xylem (Wilson 2013; Pittermann et al. 2010). All Paleozoic conifers have bordered pits with simple pit membranes, i.e., devoid of a torus (Wilson \& Knoll 2010). Pre-Cretaceous occurrences of fossil wood with a welldefined torus-margo are very rare and sometimes questionable (Holden 1915), but the presence of torus-margo pit membranes is documented in many coniferous fossil woods from the Cretaceous on (Schmid 1967). Nevertheless, there are recent reports of torus-margo pit membranes from the middle Triassic of Argentina (Bodnar et al. 2015) and the basal Jurassic of France (Moreau et al. 2019) (Fig. 2).

In sum, the combination of fossil data and modelling thus shows that homoxylous woods in fossil seed plants displayed a wide range of hydraulic properties resulting from (1) a rapid increase in anatomical diversity in the Carboniferous, and (2) the advent of torus-margo pit membranes possibly as early as the Triassic.

\section{VESSELS AND EARLY ANGIOSPERM EVOLUTION}

Vessels are water-conducting units consisting of several non-living cells (vessel elements) that are connected vertically by perforated end walls (perforation plates). Unlike the pits found on the lateral walls of tracheids, perforation plates lack a pit membrane and are complete holes through both primary and secondary walls. The end wall can have one (simple perforation plate) or several perforations (multiple perforation plate). In the latter case, the perforations can be scalariform, reticulate, or foraminate (grouped circular) (Esau 1965; IAWA Committee 1989). Vessel elements are thought to have evolved by dissolution of the 
primary wall in certain areas of the end wall of tracheids. Vessels range from a few millimeters to several meters in length and can exceed $500 \mu \mathrm{m}$ in diameter, in some angiosperm lianas (e.g., Angyalossy et al. 2015; Apgaua et al. 2017).

The presence of vessels is generally associated with the wood of angiosperms and the evolution of vessels has often been cited as one of the main reasons for the evolutionary success of angiosperms, due to the putative increase in hydraulic conductivity that it entailed (e.g., Bailey 1944; Carlquist 1975; Bond 1989). However, not all angiosperm have vessels and vessels have also been reported in other living and extinct plant groups. Among freesporing vascular plants, vessels have been reported in the primary xylem of lycopsids, such as Selaginella, of the sphenopsid Equisteum, and of several filicopsids, such as Pteridium (Duerden 1934; Bailey 1944; Bierhorst 1958; Carlquist \& Schneider 1997; Schneider \& Carlquist 2000; Fig. 8A-C). It is generally agreed that the vessels of these plants have evolved independently from those found in spermatophytes.

In the spermatophytes, vessels are present in the angiosperms, the gnetales ( Fig. 8EG) and the extinct Gigantopteridales (Li et al. 1996; Li \& Taylor 1999; Figs. 2, 8D). The oldest occurrence of vessels in spermatophytes was reported in small stems of late Permian age (ca. $270 \mathrm{Ma}$ ) assigned to the Gigantopteridales, a group of unclear affinities from the Permian-Triassic (Li et al. 1996; Li \& Taylor 1999; Fig. 1; Fig. 8D). Vessels in the wood of Vasovinea tiannii are $150-250 \mu \mathrm{m}$ in diameter, more rarely up to $500 \mu \mathrm{m}$, and each vessel element is $4.5-5 \mathrm{~mm}$ long. The perforation plates superficially resemble those commonly found in gnetales (foraminate perforation plates, Fig. 8G) but can be distinguished from the latter by a few characters, including the high number of pores (about 14 rows) and the presence of pores that bear remnants of primary wall. One putative vessel observed in the primary xylem shows a scalariform perforation plate more similar to those found in angiosperms. Tian and $\mathrm{Li}$ (1992) also reported the presence of "scalariform-reticulate 
perforation plates" in some primary xylem tracheary elements of Guizhouoxylon, another available for vessels in the secondary xylem of spermatophytes prior to the Cretaceous, almost 150 million years after the Gigantopteridales (Fig. 2).

Permian and Triassic polyplicate pollen grains reminiscent of gnetalean pollen are the oldest putative evidence for the Gnetales. By the Cretaceous they are well represented in the fossil record by pollen, charcoalified seeds, and impressions/compressions of reproductive and vegetative structures (Friis et al. 2011). There is, however, no convincing record of fossil gnetalean wood and hypotheses about wood evolution in this group (e.g., Carlquist 2012) are based exclusively on extant taxa. Vessel diameters are broadly variable within the group, from around $15 \mu \mathrm{m}$ in the desert plant Welwitschia to $>400 \mu \mathrm{m}$ in some lianescent Gnetum species (Fischer \& Ewers 1995).

Despite recent claims of Jurassic angiosperms and even older pollen exhibiting angiospermous features (reviewed by Herendeen et al. 2016), the oldest widely accepted fossil evidence for angiosperms consists of pollen from the Early Cretaceous (Hauterivian, ca 130 Ma; Brenner \& Bickoff 1992). Macrofossil evidence in the form of flowers and leaves documents significant diversification of the group throughout the Cretaceous (see Friis et al. 2011 for a review of the angiosperm fossil record). The oldest unequivocal angiosperm woods with vessels date to the Albian, 110-100 million years ago (Herendeen et al. 1999). The vessels in these woods have either simple (e.g., Paraphyllanthoxylon) or scalariform (e.g., Icacinoxylon) perforation plates, with some taxa having both types of perforations (Baas \& Wheeler 1996; Wheeler \& Baas 2019, this issue). Whereas wide vessels (>200 $\mu \mathrm{m}$ ) occur in some of the earliest angiosperm woods (Albian-Cenomanian), mean tangential vessel diameter is $<100 \mu \mathrm{m}$ in most Cretaceous angiosperm woods (Wheeler \& Baas 2019, this issue). In one Late Cretaceous (Maastrichtian) assemblage with ten wood types, maximum 
vessel diameters ranged from 80-250 $\mu \mathrm{m}$ (Olmos Formation, Mexico; Martinez-Cabrera \& Estrada-Ruiz 2014..

One long-standing matter of debate has been the single vs. multiple origin of vessels in the seed plants. Classical studies from the 1900's and the first cladistic analyses based on morphological characters (e.g., Doyle \& Donoghue 1986) have interpreted the occurrence of vessels in both gnetales and angiosperms as a synapomorphy supporting a close relationship between the two groups. On the other hand, detailed anatomical studies have suggested independent origins of the vessels in the two groups: the foraminate perforations typical of gnetaleans (Fig. 8G) thought to have evolved from tracheids with circular bordered pits on the end walls, and the angiosperm perforation plate from tracheids that had scalariform pits on the end walls (see Thompson 1918; Bailey 1944, 1953). Other authors (Muhamad \& Sattler 1982) have suggested that both types of perforation plates occur in the gnetales and, thus, that the two types of vessels are homologous. More recently, Fischer and Ewers (1995) and Carlquist (1996) have taken the view that the apparent similarities between gnetales and angiosperm vessels are the result of convergence. If convergent evolution is, indeed, the explanation for the vessels of angiosperms and gnetales, then the secondary xylem vessels of the Permian Gigantopteridales, with their distinctive perforation plates, could represent another instance of convergence.

Another key question is that of the putative advantage provided by vessels over tracheids and their roles in angiosperm evolution. Vessels have often been considered a key element in the success of the angiosperms (e.g., Bailey 1944; Carlquist 1975; Bond 1989). However data from both extant and fossil angiosperms suggests a more nuanced situation. First, ecophysiological studies comparing the hydraulic capacity in extant angiosperms and gymnosperms show that at small lumen diameters, below $60-70 \mu \mathrm{m}$, tracheids can be as efficient hydraulically as vessels (e.g., Hacke et al. 2005; Sperry et al. 2006; Brodribb et al. 
2012 ). Pitterman et al. (2005) showed that the hydraulic efficiency of conifer wood for a given sapwood-area exceeds that of angiosperm wood for the same average conduit diameter, in part thanks to the presence of torus-margo pits (see above). As a result, if vessel diameter is limited (as the result of selection pressures, because narrower vessels are less sensitive to embolism caused by freeze-thaw events or by drought), conifer wood can be more efficient. However, vessels have the advantage of reaching a given conductivity with lower investment in wood conduit area (Tyree et al. 1994; Feild \& Arens 2007). It is possible that the earliest angiosperm vessels did not provide a significant hydraulic advantage. If they did, it might have also caused a decreased embolism tolerance compared to contemporaneous vesselless seed plants, according to Feild and Wilson (2012). A recent study of rainforest angiosperms from New Caledonia shows that taxa bearing vessels with scalariform plates and vesselless taxa have comparable (low) hydraulic efficiency and safety (Trueba et al. in press).

The importance of vessels in angiosperm diversification, at least in its early stages, is also challenged by several lines of evidence suggesting that the earliest angiosperms were vesselless (Baas \& Wheeler 1996; Herendeen et al. 1999). Recent phylogenetic analyses of extant angiosperms place the vesselless genus Amborella (ANA grade, Fig. 1) as sister-group to all other angiosperms. Several other vesselless taxa occur in relatively basal angiosperm groups (e.g., Winteraceae; Fig. 7H), although loss of vessels in some of the latter cannot be excluded (Baas \& Wheeler 1996; Herendeen et al. 1999; Feild et al. 2002; see also Boura et al. 2019, this issue). On the other hand, the fossil record provides a counterpoint to the hypothesis of initially vesselless early angiosperms, as the oldest known angiosperm woods have vessels. Nevertheless, the oldest evidence for angiosperms, represented by pollen, predates the oldest angiosperm wood (Hickey \& Doyle 1977; Friis et al. 2011), indicating that the oldest angiosperm wood has yet to be found. Furthermore, the distinction between vesselless early angiosperm woods and non-angiosperm homoxylous woods in the fossil 
record can be problematic, especially since potentially useful characters appear to be Several Mesozoic fossil woods with homoxylous structure, like Lhassoxylon aptianum (Vozenin-Serra \& Pons 1990; Fig. 7F), Ecpagloxylon mathiesenii (Philippe et al. 2010) or one of the specimens described in Neraudeau et al. (2017; Fig. 7G), also show unusual features (respectively tangential lines of axial parenchyma, scalariform intertracheary radial pits, or very abundant axial parenchyma) compared to extant conifer taxa, so that they are sometimes described and considered as an early stage of the evolution that led to angiosperm wood types.

The high hydraulic efficiency of vessels led to a significant increase in wood anatomical diversity among angiosperms by allowing the diversification of other cell types devoted to distinct functions (Hudson et al. 2010). This diversity likely contributed to the diversification of angiosperm growth forms. The diversification of angiosperm lianas, for example, has been associated to heteroxyly (e.g., Isnard \& Feild 2015), although there are also many examples of lianas in homoxylous fossil seed plants (Burnham 2015). The fossil record suggests that Early Cretaceous (120-110 Ma) angiosperms were small-sized (see Philippe et al. 2008; Coiffard et al. 2012), with the first large angiosperm trees found in the Cenomanian and Turonian (about 100-90 Ma) (Coiffard et al. 2012; Jud et al. 2018; Saulnier et al. 2018). However, this is based mostly on high-latitude localities and more investigations of lower latitude floras are needed. Evidence of angiosperm-dominated forests with a significant diversity can be found in latest Cretaceous-Paleocene wood assemblages from India (Wheeler et al. 2017); such assemblages become more common and similar in composition to extant communities during the Eocene (Licht et al. 2014; 2015; Woodcock et al., 2019, this issue). While vessels certainly played a role in the increasing diversity of angiosperms throughout the Cretaceous, many questions remain on the evolution of their wood anatomy, especially in the context of whole-plant physiology and environmental factors. 


\section{CONCLUSIONS}

Since the first observations of anatomically preserved plants in the XIX ${ }^{\text {th }}$ century, paleobotany has contributed significant - and sometimes unexpected - data to our understanding of the evolution of plant vascular systems. Important among these is the realization that many key features of the vascular systems that we observe today appeared very early in plant evolution (i.e., in the Paleozoic, >250 million years ago, Fig. 2). This is true at various levels, from the organisation of vascular tissues within plant axes (stelar architecture, secondary tissues), to the types of conducting cells (tracheids, vessel elements), and even the fine elements of cell structure (pitting type, variation in conduit diameter). Furthermore, current advances in the methods used to model water flow in the xylem of fossil plants suggest that, as a result of these early evolutionary developments, significant differences in hydraulic properties existed as early as the Carboniferous. Another important lesson from the fossil record is that features related to xylem hydraulic properties might have ranked among the main drivers of the diversification of vascular plants in the late SilurianEarly Devonian and the evolution of secondary xylem (wood) in the Early Devonian. Finally, consideration of the rich data provided by the fossil record in a phylogenetic context raises numerous questions about the perceived homoplastic nature vs. potential single origin of major features of the vascular system, such as the presence and functional details of a vascular cambium or of vessels. Understanding the developmental mechanisms and the evolutionary and environmental constraints that led to the anatomies observed today will undoubtedly require continued study of the anatomy and physiology of extinct and extant plants. The fossil record will play an important role in these studies, as an irreplaceable source of (1) chronostratigraphic data as calibration points for the timing of main evolutionary events, and 
(2) examples of character combinations that do not exist today and can be used to test hypotheses formulated based on extant taxa or can be incorporated in such hypotheses.

\section{ACKNOWLEDGEMENTS}

We thank Jean-Yves Dubuisson for providing the outline used for Figure 1, Jean Galtier for discussions on Paleozoic wood and stele evolution, Kelly Matsunaga for discussions on the palm fossil record, Dennis K. Walker for producing the Isoetes sections, and Dario De Franceschi, Sabine Hennequin, Hongqi Li, Brigitte Meyer-Berthaud, and Romain Thomas for providing photos of fossil or extant material. We also thank Pieter Baas and Elisabeth Wheeler for the invitation to submit this paper. AMAP (Botany and Computational Plant Architecture) is a joint research unit which associates CIRAD (UMR51), CNRS (UMR5120), INRA (UMR931), IRD (R123), and Montpellier University (UM); http://amap.cirad.fr.

\section{REFERENCES}

Angyalossy V, Angeles G, Pace MR, Lima AC, Dias-Leme CL, Lohmann LG \& MaderoVega C. 2012. An overview of the anatomy, development and evolution of the vascular system of lianas. Plant Ecol. Divers. 5: 167--182.

https://doi.org/10.1080/17550874.2011.615574

Angyalossy V, Pace MR, Lima AC. 2015. Liana anatomy: a broad perspective on structural evolution of the vascular system. In: SA Schnitzer, FBongers, RJ Burnham \& FE Putz (eds.), The Ecology of Lianas: 252-287. Wiley-Blackwell, Oxford, UK.

https://doi.org/10.1002/9781118392409.ch19 
Apgaua DM, Tng DY, Cernusak LA, Cheesman AW, Santos RM, Edwards WJ \& Laurance SG. 2017. Plant functional groups within a tropical forest exhibit different wood functional anatomy. Func. Ecol. 31: 582--591. https://doi.org/10.1111/1365-2435.12787 Arnold CA. 1952. Observations on fossil plants from the Devonian of eastern north America. VI. Xenocladia medullosina. Contr. Mus. Paleontol. Univ. Michigan 9: 297--309.

Artabe A \& Brea M. 2003. A new approach to Corystospermales based on Triassic permineralized stems from Argentina. Alcheringa 27: 209--229. https://doi.org/10.1080/03115510308619353

Baas P \& Wheeler EA . 1996. Parallelism and reversibility in xylem evolution - a review. IAWA J. 17: 351--36. https://doi.org/10.1163/22941932-90000633

Bailey, IW. 1916. The structure of the bordered pits of conifers and its bearing upon the tension hypothesis of the ascent of sap. Botanical Gazette 62: 133-142.

Bailey IW. 1944. The development of vessels in angiosperms and its significance in morphological research. Am. J. Bot. 31:421--428. https://doi.org/10.1002/j.15372197.1944.tb08053.x

Bailey IW. 1953. Evolution of the tracheary tissue of land plants. Am. J. Bot. 40: 4--8. https://doi.org/10.2307/2438485.

Bauch J, Liese W \& Schultze R. 1972. The morphological variability of the bordered pit membranes in gymnosperms. Wood. Sci. Technol. 6: 165--184. https://doi.org/10.1007/BF00351575

Beck CB. 1957. Tetraxylopteris schmidtii gen. et. sp. nov., a probable pteridosperm precursor from the Devonian of New York. Am. J. Bot. 44:350--367. https://doi.org/10.2307/2438387

Beck CB. 1979. The primary vascular system of Callixylon. Rev. Palaeobot. Palynol. 28: 103-115. https://doi.org/10.1016/0034-6667(79)90003-4 
Beck CB. 2005. An introduction to plant structure and development. Cambridge University Press, NY. https://doi.org/10.1017/CBO9781139165365

Beck CB \& Stein WE. 1993. Crossia virginiana gen. et sp. nov., a new member of the Stenokoleales from the Middle Devonian of southwestern Virginia. Palaeontographica 229B: 115--134.

Beck CB \& Wight DC.1988. Progymnosperms. In: CB Beck (ed), Origin and evolution of gymnosperms: 1--84. Columbia University Press, New York.

Beck CB, Schmid R \& Rothwell GW. 1982. Stelar morphology and the primary vascular system of seed plants. Bot. Rev. 48: 691--815. https://doi.org/10.1007/BF02860874

Berry EW. 1916. A petrified palm from the Cretaceous of New Jersey. Am. J. Sci. 41: 193-197. https://doi.org/10.2475/ajs.s4-41.242.193

Bertrand P. 1935. Contribution a l'étude des Cladoxylalées de Saalfeld. Palaeontographica B 80: 101--170.

Bickner MA \& Tomescu AMF. 2019. Structurally complex, yet anatomically plesiomorphic: permineralized plants from the Emsian of Gaspé (Quebec, Canada) expand the diversity of Early Devonian euphyllophytes. IAWA J. https://doi.org/10.1163/22941932-40190234

Bierhorst D. 1958. Vessels in Equisetum. Am. J. Bot. 45: 534--537. https://doi.org/10.1002/j.1537-2197.1958.tb13162.x

Bodnar J \& Coturel EP. 2012. El origen y diversificación del crecimiento cambial atípico en plantas fósiles: procesos del desarrollo involucrado. Bol. Soc. Argent. Bot. 47: 33--70. Bodnar J, Ruiz D P, Artabe AEE, Morel EM \& Ganuza DG. 2015. Voltziales y Pinales (= Coniferales) de la Formación Cortaderita (Triásico Medio), Argentina, y su implicancia en la reconstrucción de las coníferas triásicas. Rev. Bras. Paleontol. 18: 141--160. http://dx.doi.org/10.4072/rbp.2015.1.10 
Bonacorsi NK \& Leslie AB. In press. Sporangium position, branching architecture, and the evolution of reproductive morphology in Devonian plants. Int. J. Plant Sci.

Bond WJ. 1989. The tortoise and the hare: ecology of angiosperm dominance and gymnosperm persistence. Biol. J. Linn. Soc. 36:227--249. https://doi.org/10.1111/j.10958312.1989.tb00492.x

Boura A, Saulnier G, De Franceschi D, Gomez B, Daviero-Gomez V, Pons D, Garcia G, Robin N, Boiteau J-M \& Valentin X. 2019. An early record of a vesselless angiosperm from the middle Cenomanian of the Envigne valley (Vienne, Western France). IAWA J. https://doi.org/10.1163/22941932-40190238

Bower FO. 1908. The origin of a land flora. Macmillan \& Co., Ltd., London.

Bower FO. 1926. The Ferns. Vol. II. Univ. Press, Cambridge.

Boyce CK. 2005. The evolutionary history of roots and leaves. In: NM Holbrook \& MA Zwieniecki (eds.).Vascular transport in plants: 479--499. Elsevier, Amsterdam. https://doi.org/10.1016/B978-012088457-5/50025-3

Boyce CK, Cody GD, Fogel ML, Hazen RM, Alexander CMOD \& Knoll AH. 2003. Chemical evidence for cell wall lignification and the evolution of tracheids in early Devonian plants. Int. J. Plant Sci. 164: 691--702. https://doi.org/10.1086/377113

Brenner GJ \& Bickoff IS. 1992. Palynology and age of the Lower Cretaceous basal Kurnub Group from the coastal plain to the northern Negev of Israel. Palynology 16(1): 137--185. https://doi.org/10.1080/01916122.1992.9989411

Brodribb TJ, Pittermann J \& Coomes DA. 2012. Elegance versus speed: Examining the competition between conifer and angiosperm trees. Int. J. Plant Sci. 173: 673--694. https://doi.org/10.1086/666005 
Burnham R.J. 2015. Climbing plants in the fossil record: Paleozoic to Present. In: SA Schnitzer, F Bongers, RJ Burnham \& FE Putz (eds.) The Ecology of Lianas: 205--220. Wiley-Blackwell, Oxford, UK. https://doi.org/10.1002/9781118392409.ch16

Carlquist S. 1975. Ecological strategies of xylem evolution. Univ. Calif. Press, Berkeley, Los Angeles \& London.

Carlquist S. 1996. Wood, bark, and stem anatomy of gnetales: a summary. Int. J. Plant Sci., 157:S58--S76. https://doi.org/10.1086/297404

Carlquist S. 2012. Wood anatomy of Gnetales in a functional, ecological, and evolutionary context. Aliso 30: 33--47. https://doi.org/10.5642/aliso.20123001.05.

Carlquist S \& Schneider EL. 1997. SEM studies on vessels in ferns. 2. Pteridium. Am. J. Bot. 84: 581--585. https://doi.org/10.2307/2445893

Cascales-Miñana B, Gerrienne P, Sirjacq B \& Steemans P. 2019. On the hydraulic conductance of three woody Devonian plants. IAWA J. https://doi.org/10.1163/22941932-40190232

Cascales-Miñana B, Steemans P, Servais T, Lepot K \& Gerrienne P. 2019. An alternative model for the earliest evolution of vascular plants. Lethaia. https://doi.org/10.1111/let.12323

Choat B, Cobb AR \& Jansen S. 2008. Structure and function of bordered pits: new discoveries and impacts on whole-plant hydraulic function. New Phytol. 177: 608--626. https://doi.org/10.1111/j.1469-8137.2007.02317.x

Chomicki G, Coiro M \& Renner SS. 2017. Evolution and ecology of plant architecture: integrating insights from the fossil record, extant morphology, developmental genetics and phylogenies. Ann. Bot. 120: 855--891. https://doi.org/10.1093/aob/mcx113 
Cichan MA. 1985. Vascular cambium and wood development in Carboniferous plants. II. Spenophyllum plurifoliatum Williamson and Scott (Sphenophyllales). Bot. Gaz. 146: 395--403. https://doi.org/10.1086/337539

Cichan MA 1986. Conductance in the wood of selected Carboniferous plants. Paleobiology 12: 302--310. https://doi.org/10.1017/S0094837300013804

Cichan MA \& Taylor TN. 1982. Vascular cambium development in Sphenophyllum: a Carboniferous arthrophyte. IAWA Bull. 3: 155--160. https://doi.org/10.1163/22941932$\underline{90000830}$

Cichan MA \& Taylor TN. 1990. Evolution of cambium in geologic time - a reappraisal. In: M Iqbal (ed.), The vascular cambium: 213--228. Research Studies Press / Wiley, Taunton, England / New York.

Cichan MA, Taylor TN \& Smoot EL. 1981. The application of scanning electron microscopy in the characterization of Carboniferous lycopod wood. Scanning Electron Microscopy 3: 197--201.

Coiffard C, Gomez B, Daviero-Gomez V \& Dilcher DL. 2012. Rise to dominance of angiosperm pioneers in European Cretaceous environments. Proc. Nat. Acad. Sci. 109: 20955--20959. https://doi.org/10.1073/pnas.1218633110

Crane PR. 1985. Phylogenetic analysis of seed plants and the origin of angiosperms. Ann. Mo. Bot. Gard. 72: 716--793. https://doi.org/10.2307/2399221

Crepet WL, \& Niklas KJ. 2019 (in press). The evolution of early vascular plant complexity. Int. J. Plant Sci.

Crié L. 1892. Recherches sur les Palmiers silicifiés des terrains crétacés de I'Anjou. Bull. Soc. Etudes Scient. Angers. 21: 99.

Cruiziat P, Cochard H \& Améglio T. 2002. Hydraulic architecture of trees: main concepts and results Ann. For. Sci. 59, 723--752. https://doi.org/10.1051/forest:2002060 
Decombeix A-L, Bomfleur B, Taylor EL \& Taylor TN. 2014. New insights into the anatomy, development, and affinities of corystosperm trees from the Triassic of Antarctica. Rev. Palaeobot. Palynol. 203: 22--34. https://doi.org/10.1016/j.revpalbo.2014.01.002

Decombeix A-L, Meyer-Berthaud B, Galtier J, Talent J \& Mawson R. 2011. Diversity of arborescent lignophytes in the Tournaisian vegetation of Queensland (Australia):

paleoecological and paleogeographical significance. Palaeog. Palaeoclimatol. Palaeoecol. 301: 39--55. https://doi.org/10.1016/j.palaeo.2010.12.017

Delevoryas T. 1964. Ontogenetic studies of fossil plants. Phytomorphology 14: 299--314.

Doyle JA \& Donoghue MJ. 1986. Seed plant phylogeny and the origin of angiosperms: an experimental cladistic approach. Bot. Rev.52: 331--429.

https://doi.org/10.1007/BF02861082

Duerden H. 1934. On the occurrence of vessels in Selaginella. Ann. Bot. 48: 459--465. https://doi.org/10.1093/oxfordjournals.aob.a090458

Dunn MT. 2006. A review of permineralized seed fern stems of the Upper Paleozoic. J. Torrey Bot. Soc. 133:20--32. https://doi.org/10.3159/10955674(2006)133[20:AROPSF]2.0.CO;2

Dute RR. 2015. Development, structure, and function of torus-margo pits in conifers, ginkgo and dicots. In: Hacke U (ed.), Functional and ecological xylem anatomy: 77--102. Springer, Cham. https://doi.org/10.1007/978-3-319-15783-2_3

Edwards 2003. Xylem in early tracheophytes. Plant Cell Environ. 26: 57--72. https://doi.org/10.1046/j.1365-3040.2003.00878.x

Edwards D \& Davies ECW. 1976. Oldest recorded in situ tracheids. Nature 263: 494--495. https://doi.org/10.1038/263494a0

Edwards D, Davies ECW \& Axe L. 1992. A vascular conducting strand in the early land plant Cooksonia. Nature 357: 683-685. https://doi.org/10.1038/357683a0 
Edwards D, Li C.-S \& Raven JA. 2006. Tracheids in an early vascular plant: a tale of two branches. Bot. J. Linn. Soc. 150: 115--130. https://doi.org/10.1111/j.10958339.2006.00450.x

Edwards D, Kenrick P \& Dolan L. 2017. History and contemporary significance of the Rhynie cherts - our earliest preserved terrestrial ecosystem. Phil.Trans. Roy. Soc. B 373: 20160489. doi: $\underline{10.1098 / \text { rstb.2016.0489 }}$

Eggert DA. 1961. The ontogeny of Carboniferous arborescent Lycopsida. Palaeontographica B 108: 43--92.

Esau K. 1965. Plant anatomy, 2nd ed. Wiley \& Sons, New York-London-Sydney.

Feild TS \& Arens NC. 2007. The ecophysiology of early angiosperms. Plant Cell Environ. 30: 291--309. https://doi.org/10.1111/j.1365-3040.2006.01625.x

Feild TS \& Wilson JP. 2012. Evolutionary voyage of angiosperm vessel structure-function and its significance for early angiosperm success. Int. J. Plant Sci. 173: 596--609. https://doi.org/10.1086/666099

Feild TS, Brodribb T \& Holbrook NM. 2002. Hardly a relict: freezing and the evolution of vesselless wood in Winteraceae. Evolution 56: 464--478. https://doi.org/10.1111/j.00143820.2002.tb01359.x

Fisher JB \& Ewers FW. 1995. Vessel dimensions in liana and tree species of Gnetum (Gnetales). Am. J. Bot. 82: 1350--1357. https://doi.org/10.2307/2445861

Friedman WE \&Cook ME. 2000. The origin and early evolution of tracheids in vascular plants: integration of palaeobotanical and neobotanical data. Phil. Trans. R. Soc. Lond. B 355: 857--868. doi: 10.1098/rstb.2000.0620 
Friis EM, Crane PR \& Pedersen KR. 2011. Early Flowers and Angiosperm Evolution.

Cambridge University Press, Cambridge, UK. https://doi.org/10.1017/CBO9780511980206

Galtier J. 1992. On the earliest arborescent gymnosperms. Cour. Forsch.-Inst. Senckenberg 147: 119--125.

Galtier J. 2010. The origins and early evolution of the megaphyllous leaf. Int. J. Plant Sci. 171: 641--661. https://doi.org/10.1086/653130

Galtier J \& Meyer-Berthaud B. 2006. The diversification of early arborescent seed ferns. J. Torrey Bot. Soc. 133: 7--19. https://www.jstor.org/stable/20063819

Gensel PG. 2018. Early Devonian woody plants and implications for the early evolution of vascular cambia. In: M Krings, NR Cúneo, CJ Harper \& GW Rothwell (eds.), Transformative paleobotany. Papers to commemorate the life and legacy of Thomas N. Taylor: 21-33. Academic Press / Elsevier. https://doi.org/10.1016/B978-0-12-813012$\underline{4.00002-4}$

Gensel PG, Kotyk ME \& Basinger JF. 2001. Morphology of above- and below-ground structures in the Early Devonian (Pragian-Emasian) plants. In: PG Gensel \& D Edwards (eds.). Plants Invade the Land: Evolutionary and Environmental Perspectives: 83-102. Columbia University Press, New York.

Gerrienne P \& Gensel PG. 2016. New data about anatomy, branching, and inferred growth patterns in the Early Devonian plant Armoricaphyton chateaupannense, Montjean-surLoire, France. Rev. Palaeobot. Palynol. 224: 38--53.

https://doi.org/10.1016/j.revpalbo.2015.07.014

Gerrienne P, Gensel PG, Strullu-Derrien C, Lardeux H, Steemans P \& Prestianni C. 2011. A simple type of wood in two Early Devonian plants. Nature 333: 837.

https://doi.org/10.1126/science.1208882 
Gifford EM \& Foster AS. 1989. Morphology and evolution of vascular plants, 3rd ed. WH Freeman \& Co., New York.

Göppert HR and Stenzel G. 1882. Die Medulloseae. Eine neue Gruppe der fossilen Cycadeen. Palaeontographica 28: 111--128.

Gonez G \& Gerrienne P. 2010. A new definition and a lectotypification of the genus

Cooksonia Lang 1937. Int. J. Plant Sci.171: 199--215. https://doi.org/10.1086/648988

Gray J \& Boucot AJ. 1977. Early vascular plants: proof and conjecture. Lethaia 10: 145--174. https://doi.org/10.1111/j.1502-3931.1977.tb00604.x

Hacke UG, Sperry JS, Pockman WT, Davis SD \& McCulloh KA. 2001. Trends in wood density and structure are linked to prevention of xylem implosion by negative pressure. Oecologia 126: 457--461.https://doi.org/10.1007/s004420100628

Hacke UG, Sperry JS \& Pittermann J. 2005. Efficiency versus safety tradeoffs for water conduction in angiosperm vessels versus gymnosperm tracheids. In: NM Holbrook \& MA Zwieniecki (eds.), Vascular transport in plants: 333-353. Elsevier, Amsterdam. https://doi.org/10.1016/B978-012088457-5/50018-6

He J, Wang S-J, Hilton J \& Shao L. 2013. Xuanweioxylon scalariforme gen. et sp. nov.: Novel Permian coniferophyte stems with scalariform bordered pitting on secondary xylem tracheids. Rev. Palaeobot. Palynol. 197: 152-165.

https://doi.org/10.1016/j.revpalbo.2013.05.010

Herendeen PS, Wheeler EA \& Baas P. 1999. Angiosperm wood evolution and the potential contribution of paleontological data. Bot. Rev. 65: 278--300. https://doi.org/10.1007/BF02857632

Herendeen PS, Friis EM, Pedersen KR \& Crane PR. 2017. Palaeobotanical redux: revisiting the age of the angiosperms. Nature Plants 3: 17015. doi: 10.1038/nplants.2017.15 
Hetherington AJ \& Dolan L. 2018. Rhynie chert fossils demonstrate the independent origin and gradual evolution of lycophyte roots. Curr. Opin. Plant Biol. 47: 119--126. https://doi.org/10.1016/j.pbi.2018.12.001

Hickey LJ \& Doyle JA. 1977. Early Cretaceous fossil evidence for angiosperm evolution. Bot. Rev. 43: 3--104. https://doi.org/10.1007/BF02860849

Hoffman LA \& Tomescu AMF. 2013. An early origin of secondary growth: Franhueberia gerriennei gen. et sp. nov. from the Lower Devonian of Gaspé (Quebec, Canada). Am. J. Bot. 100: 754--763. https://doi.org/10.3732/ajb.1300024

Holden R. 1915. A Jurassic wood from Scotland. New Phytol. 14: 205--209. https://doi.org/10.1111/j.1469-8137.1915.tb07187.x

Hudson PJ, Razanatsoa J \& Feild TS. 2010. Early vessel evolution and the diverisification ofwood function: Insights from Malagasy Canellales. Am. J. Bot. 97: 80--93. https://doi.org/10.3732/ajb.0900130

Isnard S \& Feild TS. 2015. The evolution of angiosperm lianescence : a perspective from xylem structure-function. In: SA Schnitzer, FBongers, RJ Burnham \& FE Putz (eds.), The Ecology of Lianas: 221-238. Wiley-Blackwell, Oxford, UK.

https://doi.org/10.1002/9781118392409.ch17

Jansen S, Choat B, Vinckier S, Lens F, Schols P \& Smets E. 2004. Intervascular pit membranes with a torus in the wood of Ulmus (Ulmaceae) and related genera. New Phytol. 163: 51--59. https://doi.org/10.1111/j.1469-8137.2004.01097.x

Jud NA, D’Emic MD, Williams SA, Mathews JC., Tremaine KM \& Bhattacharya,J. 2018. A new fossil assemblage shows that large angiosperm trees grew in North America by the Turonian (Late Cretaceous). Science Advances 4: eaar8568. https://doi.org/10.1126/sciadv.aar8568 
Kenrick P \& Crane PR. 1991: Water-conducting cells in early fossil land plants: implications for the Early Evolution of Tracheophytes. Bot. Gaz.152: 335--336. https://doi.org/10.1086/337897

Kenrick P \& Crane PR. 1997. The origin and early diversification of land plants. Smithsonian Institution Press, Washington, D.C.

Kenrick P, Wellman CH, Schneider H \& Edgecombe GD. 2012. A timeline for terrestrialization: consequences for the carbon cycle in the Palaeozoic. Phil. Trans. R. Soc. B 367: 519--536. https://doi.org/10.1098/rstb.2011.0271

Kotyk ME, Basinger JF, Gensel PG \& de Freitas TA. 2002. Morphologically complex plant macrofossils from the Late Silurian of Arctic Canada. Am. J. Bot. 89: 1004--1013. https://doi.org/10.3732/ajb.89.6.1004

Lang WH. 1937. On the plant-remains from the Downtonian of England and Wales. Phil. Trans. R. Soc. B227: 245--291. https://doi.org/10.1098/rstb.1937.0004

Langdale JA \& Harrison CJ. 2008. Developmental transitions during the evolution of plant form. In: A Minelli \& G Fusco (eds.), Evolving pathways. Key themes in evolutionary developmental biology: 299-315. Cambridge University Press, Cambridge, UK.

Li H \& Taylor DW. 1999. Vessel-bearing stems of Asovinea tianii gen. et sp. nov. (Gigantopteridales) from the Upper Permian of Guizhou Province, China. Am. J. Bot. 86: 1563--75. https://doi.org/10.2307/2656794

Li H, Taylor EL \& Taylor TN. 1996. Permian vessel elements. Science 271: 188--189. https://doi.org/10.1126/science.271.5246.188

Libertin M, Kvacek J, Bek J, Zarsky V \& Storch P. 2018. Sporophytes of polysporangiate land plants from the early Sil-urian period may have been photosynthetically autonomous. Nature Plants 4: 269271. https://doi.org/10.1038/s41477-018-0140-y 
Licht A, Boura A, De Franceschi D, Ducrocq S, Soe AN \& Jaeger JJ. 2014. Fossil woods from the late middle Eocene Pondaung Formation, Myanmar. Rev. Paleobot. Palynol. 202: 29--46. https://doi.org/10.1016/j.revpalbo.2013.12.002

Licht A, Boura A, De Franceschi D, Utescher T, Sein C \& Jaeger JJ. 2015. Late middle Eocene fossil wood of Myanmar: Implications for the landscape and the climate of the Eocene Bengal Bay. Rev. Paleobot. Palynol. 216: 44--54. https://doi.org/10.1016/j.revpalbo.2015.01.010

Martin F. 1971. Palynofacies et microfacies du Silurien inférieur à Deerlijk. Bulletin de l'Institut Royal des Sciences Naturelles de Belgique, Biologie 47: 1--26.

Martínez-Cabrera HI \& Estrada-Ruiz E. 2014. Wood anatomy reveals high theoretical hydraulic conductivity and low resistance to vessel implosion in a Cretaceous fossil forest from Northern Mexico. PLoS ONE 9: e108866. https://doi.org/10.1371/journal.pone.0108866

Matten LC. 1992. Studies on Devonian plants from New York State: Stenokoleos holmesii n. sp. from the Cairo Flora (Givetian) with an alternative model for lyginopterid seed fern evolution. Cour. Forsch. Inst. Senckenberg 147: 75--85.

McCulloh KA, Sperry JS \& Adler FR. 2003. Water transport in plants obeys Murray's law. Nature 421: 939--942. https://doi.org/10.1038/nature01444

Meyer-Berthaud B \& Decombeix A-L. 2009. Evolution of first trees: the Devonian strategies. C. R. Palevol 8: 155--165. https://doi.org/10.1016/j.crpv.2008.08.002

Momont N, Decombeix A-L, Gerrienne P \& Prestianni C. 2016. New information, including anatomy of the secondary xylem, on the genus Brabantophyton (Stenokoleales) from Ronquières (Middle Devonian, Belgium). Rev. Palaeobot. Palynol. 234: 44--60. https://doi.org/10.1016/j.revpalbo.2016.08.009 
Moreau JD, Philippe M \& Thévenard F. 2019. Flore du Jurassique basal de la ville de Mende (Lozère): synthèse des gisements historiques, nouvelles données sédimentologiques, paléontologiques et paléoenvironnementales. C. R. Palevol 18: 159--177. https://doi.org/10.1016/j.crpv.2018.07.002

Morris JL, Puttick MN, Clark JW, Edwards D, Kernick P, Pressel S, Wellman CH, Yang Z, Scheneider H \& Donoghue PCJ. 2018. The timescale of early land plant evolution. Proc. Nat. Acad. Sci. 115: E2274--E2283. https://doi.org/10.1073/pnas.1719588115

Morrow AC \& Dute RR. 1998. Development and structure of pit membranes in the rhizome of the woody fern Botrychium dissectum. IAWA J. 19:429--441. https://doi.org/10.1163/22941932-90000664

Mosbrugger V. 1990. The tree habit in land plants. Lecture Notes in Earth Sciences 28 Springer-Verlag, Berlin. https://doi.org/10.1007/BFb0011397

Muhammad AF \& Sattler R. 1982. Vessel structure of Gnetum and the origin of Angiosperms. Am. J. Bot. 69: 1004--1021. https://doi.org/10.1002/j.1537-2197.1982.tb13345.x

Namboodiri KK \& Beck CB. 1968. A comparative study of the primary vascular system of conifers. III. Stelar evolution in gymnosperms. Am. J. Bot. 55: 464--472. https://doi.org/10.2307/2440576

Néraudeau D, Perrichot V, Batten DJ, Boura A, Girard V, Jeanneau L \& Thomas R. 2017. Upper Cretaceous amber from Vendée, north-western France: age dating and geological, chemical, and palaeontological characteristics. Cretac. Res. 70: 77--95. https://doi.org/10.1016/j.cretres.2016.10.001

Nguyen C, Andrews A, Baas P, Bond JE, Auad M \& Dute R. 2017. Pit membranes and their evolution in the Oleinae of the Oleaceae. IAWA J. 38: 201--219.

https://doi.org/10.1163/22941932-20170168 
Niklas KJ. 1994. Plant allometry: the scaling of form and process. University of Chicago Press, Chicago.

Ohtani J. 1983. SEM investigation on the micromorphology of vessel wall sculptures. Research Bulletin of the College Experiment Forests, College of Agriculture, Hokkaido University 40: 323--386.

Ohtani J \& Ishida S. 1978. Pit membrane with torus in dicotyledonous woods [angiosperm tree]. Journal of the Japan Wood Research Society 24: 673--675.

Pace MR, Acevedo-Rodriguez P, Amorim AM \& Angyalossy V. 2018a. Ontogeny, structure and occurrence of interxylary cambia in Malpighiaceae. Flora 241: 46--60.

https://doi.org/10.1016/j.flora.2018.02.004

Pace MR, Angyalossy V, Acevedo-Rodriguez P, Wen J. 2018b. Structure and ontogeny of successive cambia in Tetrastigma (Vitaceae), the host plants of Rafflesiaceae. J. Syst. Evol. 56: 394--400. https://doi.org/10.1111/jse.12303

Paolillo DJ, Jr. 1963. The developmental anatomy of Isoetes. Illinois Biological Monographs 31. University of Illinois Press, Urbana.

Pfeiler KC \& Tomescu AMF. 2018. An Early Devonian permineralized rhyniopsid from the Battery Point Formation of Gaspé (Canada). Bot. J. Linn. Soc. 187: 292--302. https://doi.org/10.1093/botlinnean/boy011

Philippe M, Gomez B, Girard V, Coiffard C, Daviero-Gomez V, Thevenard F, Billon-Bruyat J-P, Guiomard M, Latil J-L, Le Loeuff J, Néraudeau D, Olivero D \& Schlögl J. 2008. Woody or not woody? Evidence for early angiosperm habit from the Early Cretaceous fossil wood record of Europe. Paleoworld 17: 142--152. https://doi.org/10.1016/j.palwor.2008.06.001 
Philippe M, Cuny G \& Bashforth A. 2010. Ecpagloxylon mathiesenii gen. nov. et sp. nov., a Jurassic wood from Greenland with several primitive angiosperm features. Plant Syst. Evol. 287: 153--165. https://doi.org/10.1007/s00606-010-0308-Z

Phillips TL. 1974. Evolution of vegetative morphology in coenopterid ferns. Ann. Mo. Bot. Gard. 61: 427--461. https://doi.org/10.2307/2395067

Pigg KB \& Taylor TN. 1993. Anatomically preserved Glossopteris stems with attached leaves from the Central Transantarctic Mountains, Antarctica. Am. J. Bot. 80: 500--516. https://doi.org/10.1002/j.1537-2197.1993.tb13833.x

Pittermann J, Sperry JS, Hacke UG, Wheeler JK \& Sikkema EH. 2005. Torus-margo pits help conifers compete with angiosperms. Science 310: 1924--1924. https://doi.org/10.1126/science.1120479

Pittermann J, Sperry JS, Hacke UG, Wheeler JK \& Sikkema EH. 2006a. Inter-tracheid pitting and the hydraulic efficiency of conifer wood: the role of tracheid allometry and cavitation protection. Am. J. Bot. 93: 1265--1273. https://doi.org/10.3732/ajb.93.9.1265

Pittermann J, Sperry JS, Wheeler JK, Hacke UG \& Sikkema EH. 2006b. Mechanical reinforcement of tracheids compromises the hydraulic efficiency of conifer xylem. Plant Cell Environ. 29: 1618--1628. https://doi.org/10.1111/j.1365-3040.2006.01539.x

Pittermann J, Choat B, Jansen S, Stuart SA, Lynn L \& Dawson TE. 2010. The relationships between xylem safety and hydraulic efficiency in the Cupressaceae: the evolution of pit membrane form and function. Plant Physiology 153: 1919--1931. https://doi.org/10.1104/pp.110.158824

Pittermann J, Limm E, Rico C \& Christman MA. 2011. Structure-function constraints of tracheid-based xylem: a comparison of conifers and ferns. New Phytol. 192: 449--461. https://doi.org/10.1111/j.1469-8137.2011.03817.x 
Prestianni C, Decombeix A-L, Thorez J, Fokand D \& Gerrienne P. 2010. Famennian charcoal of Belgium. Palaeogeogr. Palaeoclimatol. Palaeoecol. 291: 60--71. https://doi.org/10.1016/j.palaeo.2009.10.008

Raven JA. 1994. Physiological analyses of aspects of the functioning of vascular tissue in early plants. Botanical Journal of Scotland 47: 49--64.

https://doi.org/10.1080/03746609408684817

Renault B. 1879. Structure comparée de quelques tiges de la flore carbonifère. Nouvelles Annales du Muséum d'Histoire Naturelle 2: 213--348.

Rößler R \& Noll R. 2006. Sphenopsids of the Permian (I): The largest known anatomically preserved calamite, an exceptional find from the petrified forest of Chemnitz, Germany. Rev. Palaeobot. Palynol. 140: 145--162. https://doi.org/10.1016/j.revpalbo.2006.03.008

Roth A \& Mossbruger V. 1996. Numerical studies of water conduction in land plants: evolution of early stele types. Paleobiology 22: 411--421. https://doi.org/10.1017/S0094837300016365

Rothwell GW. 1999. Fossils and ferns in the resolution of land plant phylogeny. Bot. Rev. 65: 188--218. https://doi.org/10.1007/BF02857629

Rothwell GW \& Serbet R. 1994. Lignophyte phylogeny and the evolution of spermatophytes: a numerical cladistic analysis. Syst. Bot. 19: 443--482. https://doi.org/10.2307/2419767

Rothwell GW, Sanders H, Wyatt SE \& Lev-Yadun S. 2008. A fossil record for growth regulation: the role of auxin in wood evolution. Ann. Mo. Bot. Gard. 95: 121--134. https://doi.org/10.3417/2006208

Rowe NP \& Speck T. 2004. Hydraulics and mechanics of plants: novelty, innovation and evolution. In: I Poole \& AR Hemsley (eds.), The evolution of plant physiology: 297-325. Elsevier Academic Press, Kew, UK. https://doi.org/10.1016/B978-012339552-8/50017-2 
Rubinstein CV, Gerrienne P, de la Punte GS, Astini RA \& Steemans P. 2010. Early Middle

Ordovician evidence for land plants in Argentina (eastern Gondwana). New Phytol. 188: 365--369. https://doi.org/10.1111/j.1469-8137.2010.03433.x

Sanders H, Rothwell GW \& Wyatt SE. 2009. Key morphological alterations in the evolution of leaves. Int. J. Plant Sci. 170: 860--868. https://doi.org/10.1086/600135

Sanders H, Rothwell GW \& Wyatt SE. 2011. Parallel evolution of auxin regulation in rooting systems. Plant Sys. Evol. 291: 221--225. https://doi.org/10.1007/s00606-010-0383-1

Saulnier G, Boura A, Bernard G, Daviero-Gomez V, De Franceschi D, Pons D, Garcia G, Boiteau J-M \& Valentin X. 2018. Diversity in Cenomanian forests: an example from the Envigne Valley (Vienne), France. 10th European Palaeobotany and Palynolog Conference, Dublin.

Scheckler SE. 1974. Systematic characters of Devonian ferns. Ann. Mo. Bot. Gard. 61: 462-473. https://doi.org/10.2307/2395068

Scheckler SE. 1976. Ontogeny of progymnosperms. I. Shoots of Upper Devonian Aneurophytales. Can. J. Bot. 54: 202--219. https://doi.org/10.1139/b76-020

Scheckler SE. 1978. Ontogeny of progymnosperms. II. Shoots of Upper Devonian Archaeopteridales. Can. J. Bot. 56: 3136--3170. https://doi.org/10.1139/b78-376

Scheckler SE \& Banks HP. 1971. Proteokalon, a new genus of progymnosperm from the Devonian of New York State and its bearing on phylogenetic trends in the group. Am. J. Bot. 58: 874--884. https://doi.org/10.2307/2441566

Schmid R. 1967. Electron microscopy of wood of Callixylon and Cordaites. Am. J. Bot. 54: 720--729. https://doi.org/10.2307/2440949

Schneider EL \& Carlquist S. 2000. SEM Studies on the vessels of heterophyllous species of Selaginella. J. Torrey Bot. Soc. 127: 263--270. https://doi.org/10.1086/317557 
Schneider H, Pryer K, Cranfill R, Smith A \& Wolf P. 2002. Evolution of vascular plant body plans: a phylogenetic perspective In: QCB Cronk, RM Bateman \& JA Hawkins (eds.), Developmental Genetics and Plant Evolution: 330-364. Taylor \& Francis, London, UK. https://doi.org/10.1201/9781420024982.ch17

Serbet R \& Rothwell GW. 1992. Characterizing the most primitive seed ferns. I. A Reconstruction of Elkinsia polymorpha. Int. J. Plant Sci. 4: 602-621. https://doi.org/10.1086/297083

Speck T \& Vogellehner D. 1988. Biophysical examinations of the bending stability of various stele types and the upright axes of early "vascular" land plants. Botanica Acta 101: 262-268. https://doi.org/10.1111/j.1438-8677.1988.tb00042.x

Speck T \& Vogellehner D. 1992. Biomechanics and maximum height of some Devonian land plants. In: J Kovar-Eder (ed.), Palaeovegetational development in Europe and regions relevant to its palaeofloristic evolution: proceedings of the Pan-European Palaeobotanical Conference, Vienna, 19-23 September 1991, PEPC 1991: 413--422. Museum of Natural History, Vienna, Austria.

Sperry JS, Hacke UG \& Pittermann J. 2006. Size and function in conifer tracheids and angiosperm vessels. Am. J. Bot. 93: 1490--1500. https://doi.org/10.3732/ajb.93.10.1490 Sperry JS, Meinzer FC \& McCulloh KA. 2008. Safety and efficiency conflicts in hydraulic architecture: scaling from tissues to trees. Plant Cell Environ. 31: 632--645. https://doi.org/10.1111/j.1365-3040.2007.01765.x

Steemans P, Le Hérissé A, Melvin J, Miller MA, Paris F, Verniers J \& Wellman CH. 2009. Origin and radiation of the earliest vascular land plants. Science 324: 353. https://doi.org/10.1126/science.1169659 
Stein WE. 1993. Modeling the evolution of stelar architecture in vascular plants. Int. J. Plant Sci. 154: 229--263. https://doi.org/10.1086/297106

Stein WE \& Beck CB. 1983. Triloboxylon arnoldii from the Middle Devonian of western New York. Contrib. Mus. Paleontol. Univ. Mich. 26: 257--288.

Stewart WN \& Rothwell GW. 1993. Paleobotany and the evolution of plants. Second edition. Cambridge University Press, Cambridge, UK.

Strullu- Derrien C, Kenrick P, Tafforeau P, Cochard H, Bonnemain J- L, Le Hérissé A, Lardeux H \& Badel E. 2014. The earliest wood and its hydraulic properties documented in c. 407- million- year- old fossils using synchrotron microtomography. Bot. J. Linn. Soc. 175: 423--437. https://doi.org/10.1111/boj.12175

Tanrattana M, Barczi J-F, Decombeix A-L, Meyer-Berthaud B \& Wilson JP. 2019. A new approach for modelling water transport in fossil plants. IAWA J.

Taylor TN, Taylor EL \& Krings M. 2009. Paleobotany: The Biology and Evolution of Fossil Plants. Second ed. Academic Press, Amsterdam.

Taylor WA \& Wellman CH. 2009. Ultrastructure of enigmatic phytoclasts (banded tubes) from the Silurian-Lower Devonian: evidence for affinities and role in early terrestrial ecosystems. Palaios 24: 167--180. https://doi.org/10.2110/palo.2008.p08-046r

Terreaux de Félice H, Decombeix A-L \& Galtier J. In press. Anatomy, affinities, and evolutionary implications of new silicified stems of Sphenophyllum from the early Carboniferous (Mississippian) of France and Germany. Geodiversitas.

Thompson WP. 1918. Independent evolution of vessels in Gnetales and Angiosperms. Bot. Gaz. 65: 83--90. https://doi.org/10.1086/332191 
Tian BL \& Li HQ. 1992. A new special petrified stem, Guizhouoxylon dahebianense gen. et sp. nov., from Upper Permian in Suicheng district, Guizhou, China. Acta Palaeontol. Sin. 31: 336--345 [in Chinese with English Abstract].

Toledo S, Bippus AC \& Tomescu AMF. 2018. Buried deep beyond the veil of extinction: euphyllophyte relationships at the base of the spermatophyte clade. Am. J. Bot. 105: 1264--1285. https://doi.org/10.1002/ajb2.1102

Tomescu AMF. 2009. Megaphylls, microphylls and the evolution of leaf development. Trends Plant Sci. 14: 5--12. https://doi.org/10.1016/j.tplants.2008.10.008

Tomescu AMF \& Groover AT. 2019. Mosaic modularity: an updated perspective and research agenda for the evolution of vascular cambial growth. New Phytol. https://doi.org/10.1111/nph.15640

Trueba S, Delzon S, Isnard S \& Lens F. 2019. Similar hydraulic efficiency and safety across vesselless angiosperms and vessel-bearing species with scalariform perforation plates. J. Exp. Bot. https://doi.org/10.1093/jxb/erz133

Tyree MT \& Ewers FW. 1991. The hydraulic architecture of trees and other woody plants, New Phytol. 119: 345--360. https://doi.org/10.1111/j.1469-8137.1991.tb00035.x

Tyree MT, Davis SD \& Cochard H. 1994. Biophysical perspectives of xylem evolution: is there a tradeoff of hydraulic efficiency for vulnerability to dysfunction? IAWA J. 15(4): 335--360. https://doi.org/10.1163/22941932-90001369

Unger HR. 1847. Chloris protogæa. Beiträge zur flora der vorwelt. W Engelmann, Leiptzig. https://doi.org/10.5962/bhl.title.141709

Vozenin-Serra C \& Pons D. 1990. Intérêts phylogénétique et paléoécologique des structures ligneuses homoxylées découvertes dans le Crétacé inférieur du Tibet méridional. Palaeontographica 126B:107--127. 
Wellman CH. 2018. Palaeoecology and palaeophytogeography of the Rhynie chert plants:

further evidence from integrated analysis of in situ and dispersed spores. Philos. Trans. R. Soc. Lond. B Biol. Sci. 373: 20160491. https://dx.doi.org/10.1098\%2Frstb.2016.0491

Wheeler, E.A. 1983. Intervascular pit membranes in Ulmus and Celtis native to the United States. IAWA Journal 4: 79-88. https://doi.org/10.1163/22941932-90000400

Wheeler EA \& Baas P. 2019. Wood evolution: Baileyan trends and Functional traits in the fossil record. IAWA J. https://doi.org/10.1163/22941932-40190230

Wheeler EA, Srivastava R, Manchester SR \& Baas P. 2017. Surprisingly modern Latest Cretaceous- earliest Paleocene woods of India. IAWA J. 38: 456--542.

\section{https://doi.org/10.1163/22941932-20170174}

Wight DC. 1987. Non-adaptive change in early land plant evolution. Paleobiology 13: 208-214. https://doi.org/10.1017/S0094837300008757

Willis KJ. 2017. State of the world's plants 2017. Report. Royal Botanic Gardens, Kew. https://stateoftheworldsplants.org/

Wilson JP. 2013. Modeling 400 million years of plant hydraulics. The Paleontological Society Papers 19: 175--194. https://doi.org/10.1017/S1089332600002734

Wilson JP. 2016. Hydraulics of Psilophyton and evolutionary trends in plant water transport after terrestrialization. Rev. Palaeobot. Palynol. 227: 65--76.

https://doi.org/10.1016/j.revpalbo.2015.11.010

Wilson JP \& Knoll AH. 2010. A physiologically explicit morphospace for tracheid-based water transport in modern and extinct seed plants. Paleobiology 36: 335--355. https://doi.org/10.1666/08071.1

Wilson JP, Knoll AH, Holbrook NM \& Marshall CR. 2008. Modeling fluid flow in Medullosa, an anatomically unusual Carboniferous seed plant. Paleobiology 34: 472-493. https://doi.org/10.1666/07076.1 
Witham HTM. 1831. Observations on fossil vegetables accompanied by representation of their internal structure, as seen through the microscope. W Blackwood, Edinburgh \& T Cadell, London.

Witham HTM. 1833. The internal structure of fossil vegetables found in the carboniferous and oolitic deposits of Great Britain. A \& C Black, Edinburgh.

https://doi.org/10.5962/bhl.title.119949

Woodcock DW, Meyer HW \& Prado Y. 2019. The Piedra Chamana fossil woods (Eocene, Peru), II. IAWA J. 40: --- https://doi.org/10.1163/22941932-40190231

Xu H-H, Berry CM, Stein WE, Wang Y, Tang P \& Fu Q. 2017. Unique growth strategy of the oldest fossil trees. Proc. Nat. Acad. Sci. 114:201708241.

https://doi.org/10.1073/pnas.1708241114

Zimmermann MH. 1978. Hydraulic architecture of some diffuse-porous trees. Can. J. Bot. 56: 2286--2295. https://doi.org/10.1139/b78-274

Zimmermann W. 1959. Die Phylogenie der Pflanzen, 2nd ed. Gustav Fischer, Stuttgart, Germany. 


\section{FIGURE LEGENDS}

Fig. 1. Simplified phylogenetic tree of embryophytes and stratigraphic ranges of the main lineages. The tree topology is composite, based on several studies from the recent literature. Observed stratigraphic ranges (as documented by unambiguous fossils) shown by continuous lines. Dashed lines represent ranges hypothesized based on phylogenetic analyses or molecular dating. Extinct groups in blue; taxa in quotation marks are considered paraphyletic. Geologic time scale as adopted by the International Commission on Stratigraphy (v2018/08).

Fig. 2. First occurrences and stratigraphic ranges of main characters in vascular plant evolution discussed in this paper. Sections 1-5 correspond to the text sections. Stratigraphic ranges of early tracheid types based on Edwards (2003, Fig.1). "Modern tracheids" include both those of lycopsids and of euphyllophytes. A cambial layer in extant lycopsids is present in Isoetes (see text and Fig. 6A, B). Taxa in blue are extinct groups. Taxon names and geologic time scale as in Fig. 1.

Fig. 3. Water-conducting cells in early land plants (top) with details of their wall structure (bottom). A. Bryophyte hydroid; B. S-type tracheid (fossil) typical of rhyniopsids; C: G-type tracheid (fossil) typical of zosterophyllophytes; D: P-type tracheid (fossil) typical of trimerophyte grade plants (basal euphyllophytes). From Kenrick \& Crane 1997

Fig. 4. Stelar diversity part 1 . Dotted line $=$ epidermis, white $=$ ground tissues, grey $=$ primary phloem, black $=$ primary $x y l e m . ~ T s=$ transverse section.

A-C. Protostele; B. Ts of Gleichenia sp. stem (extant); C. Ts of Lepidodendron esnostense stem, early Carboniferous, France. 
D-F. Actinostele; E. Ts of Psilotum sp. axis (extant); F. Ts of Tristichia longii, early

Carboniferous, France.

G-I. Plectostele; H. Ts of Selaginella sp. stem (extant); I. Ts of Xenocladia medullosina, Middle Devonian, Kazakhstan.

J-L. Solenostele; K. Ts of Adiantum sp. rhizome (extant); L. Ts of Tempskya sp. rhizome, middle Cenomanian, France.

Scale bars: $\mathrm{E}=250 \mu \mathrm{m} ; \mathrm{B}, \mathrm{H}, \mathrm{K}=500 \mu \mathrm{m} ; \mathrm{C}, \mathrm{L}=1 \mathrm{~mm} ; \mathrm{F}, \mathrm{I}=2 \mathrm{~mm}$.

Fig. 5. Stelar diversity part 2. Dotted line $=$ epidermis, white $=$ ground tissues, grey $=$ primary phloem, black $=$ primary $x y l e m . ~ T s=$ transverse section.

A-C. Dictyostele; B. Ts of Polypodium sp. rhizome (extant); C. Ts of Psaronius brasiliensis stem (MNHN.F.1445 picture. R. Thomas), Permian, Brazil.

D-F. Eustele; E. Ts of Vitis vinifera stem (extant); F. Ts of Callixylon zalessky, Late Devonian, USA.

G-I. Atactostele; H. Ts of Oenocarpus sp. stem (extant); I. Ts of Palmoxylon sp., Oligocene, France.

Scale bars: $\mathrm{E}=500 \mu \mathrm{m} ; \mathrm{B}, \mathrm{I}=1 \mathrm{~mm} ; \mathrm{F}=2 \mathrm{~mm} ; \mathrm{H}=5 \mathrm{~mm} ; \mathrm{C}=5 \mathrm{~cm}$.

Fig. 6. Secondary growth. Ts $=$ transverse section.

A-B. Secondary growth from a bifacial cambium in Isoetes sp. stem (extant); A. Ts, cambium located at the periphery of lighter, vacuolated area around the central tissues; B. Radial longitudinal section, cambium located along the vertical boundaries between the lighter, vacuolated layers and the dark-nucleated layers that border them externally. 
C-E. Unifacial cambial growth; C. Ts of Lepidodendron serratum, late Carboniferous, USA;

D. Ts of Cladoxylon sp., early Carboniferous, Germany; E. Ts of Arthropitys sp., late Carboniferous, USA.

F. Bifacial cambium in Sphenophyllum sp., Permian, France.

G-H. Bifacial cambium with well-preserved secondary phloem; G. Ts of Tetraxylopteris sp., Middle Devonian, USA; H. Ts of Stanwoodia sp., early Carboniferous, Scotland.

Scale bars: $A, G, H=250 \mu \mathrm{m} ; \mathrm{B}, \mathrm{E}, \mathrm{F}=500 \mu \mathrm{m} ; \mathrm{D}=1.5 \mathrm{~mm} ; \mathrm{C}=5 \mathrm{~mm}$.

Fig. 7. Homoxylous wood. Ts = transverse section.

A. Ts; Picnoxylic wood in Callixylon sp., Late Devonian, USA.

B. Ts; Manoxylic wood in Calamopitys schweitzeri, early Carboniferous, France.

C. Tangential longitudinal section (Tls); Multiseriate rays up to 100 cells high in Eristophyton waltonii, early Carboniferous, Scotland.

D. Radial longitudinal section (Rls); Crowded multiseriate oval to oblique bordered pits with oval aperture in Callixylon sp., Late Devonian, USA.

E. Rls; Scalariform pits in Protopitys sp., early Carboniferous, France.

F-G. Ts; Unusual homoxylous wood structure in Lhassoxylon aptianum (UPMC 10468) and in a specimen from Neraudeau et al. (2017).

H. Ts; Homoxylous wood structure in Drimys sp. (Winteraceae; extant)

Scale bar D, E = $100 \mu \mathrm{m}, \mathrm{A}, \mathrm{B}=200 \mu \mathrm{m}, \mathrm{F}, \mathrm{G}=250 \mu \mathrm{m}, \mathrm{C}, \mathrm{H}=500 \mu \mathrm{m}$.

Fig. 8. Vessels and heteroxylous woods.

A-C. Vessels in the primary xylem A-B. Pteris sp. (extant) C. Tempskya sp. rhizome, middle Cenomanian, France.

D. Ts. Vessels in Vasovinea tianii (Gigantopteridales) 
E-G. Heteroxylous wood in Ephedra sp. (extant) (Gnetales), E-F. Ts, G. Rls. foraminate perforation plate.

Scale bar $\mathrm{G}=50 \mu \mathrm{m}, \mathrm{B}, \mathrm{C}=100 \mu \mathrm{m} \mathrm{A}, \mathrm{F}=200 \mu \mathrm{m} \mathrm{D}, \mathrm{E}=1 \mathrm{~mm}$. 


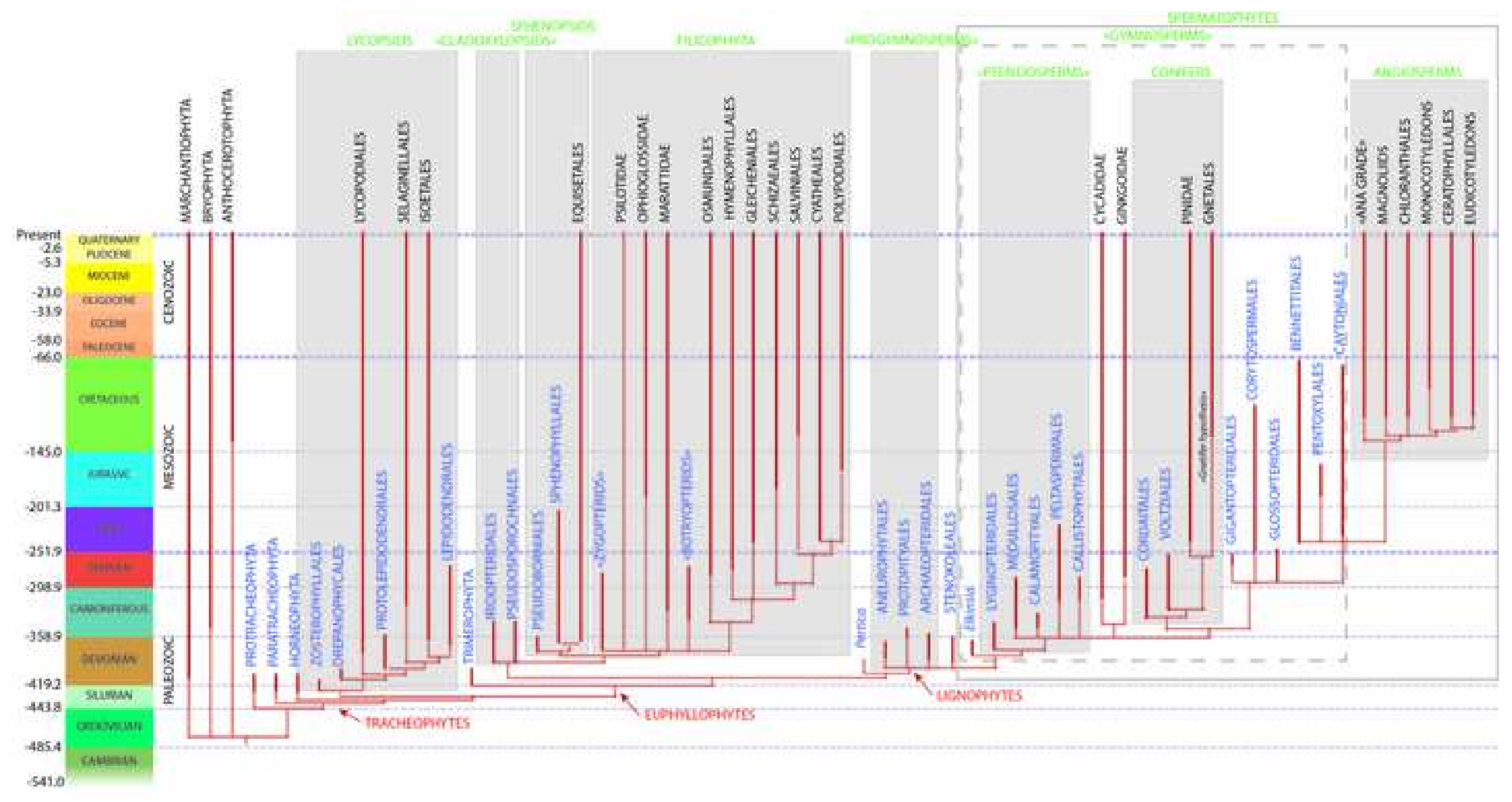




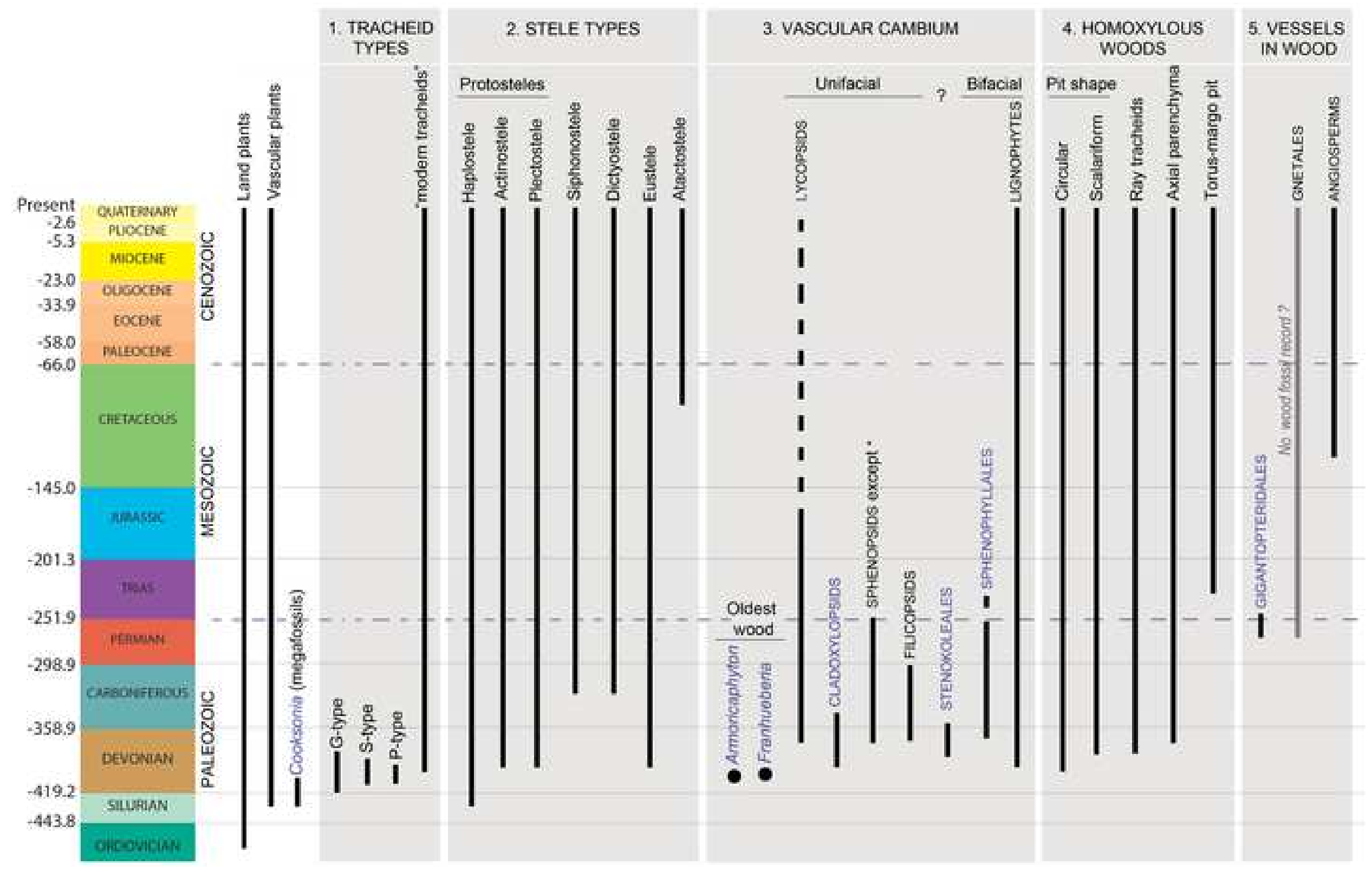



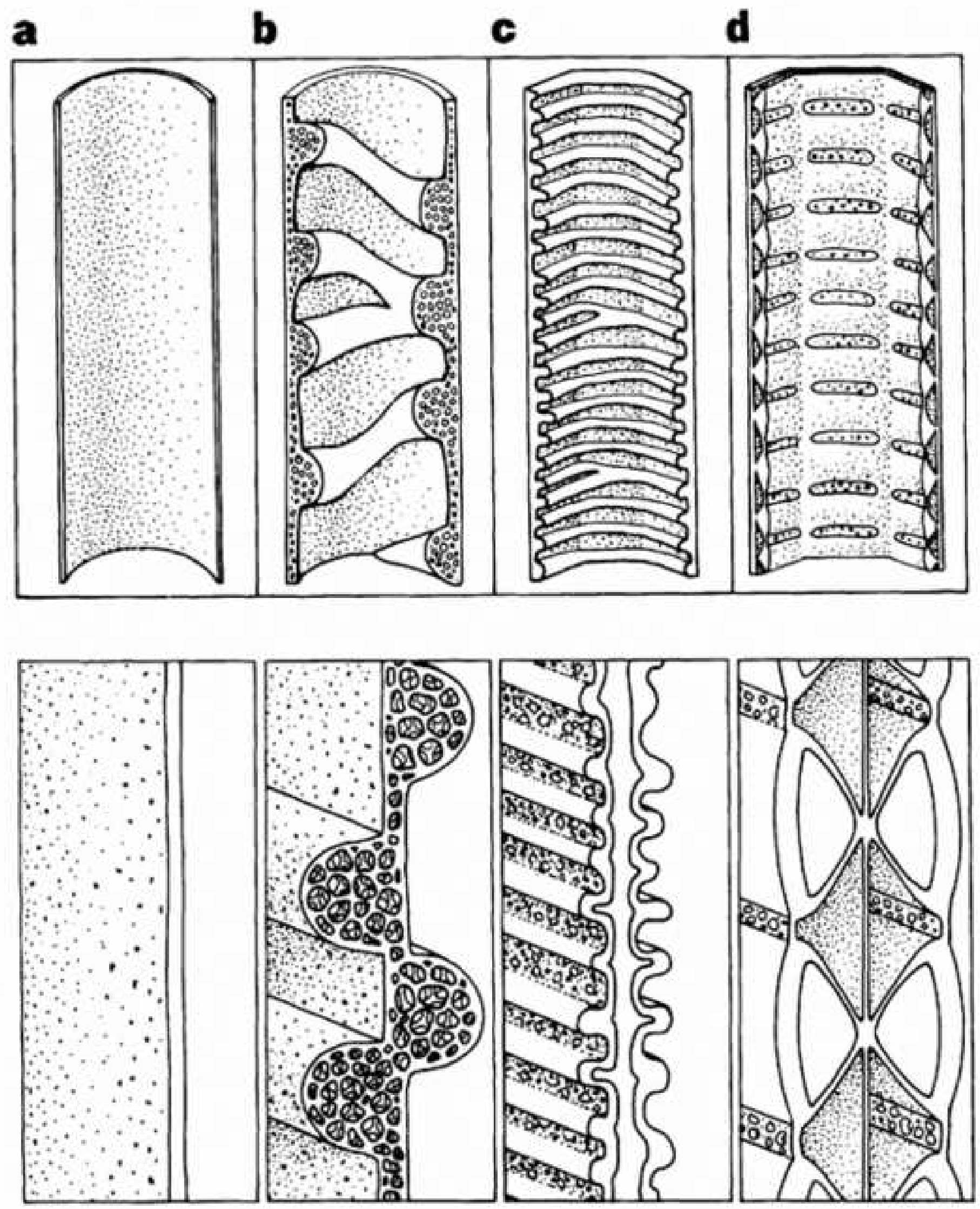

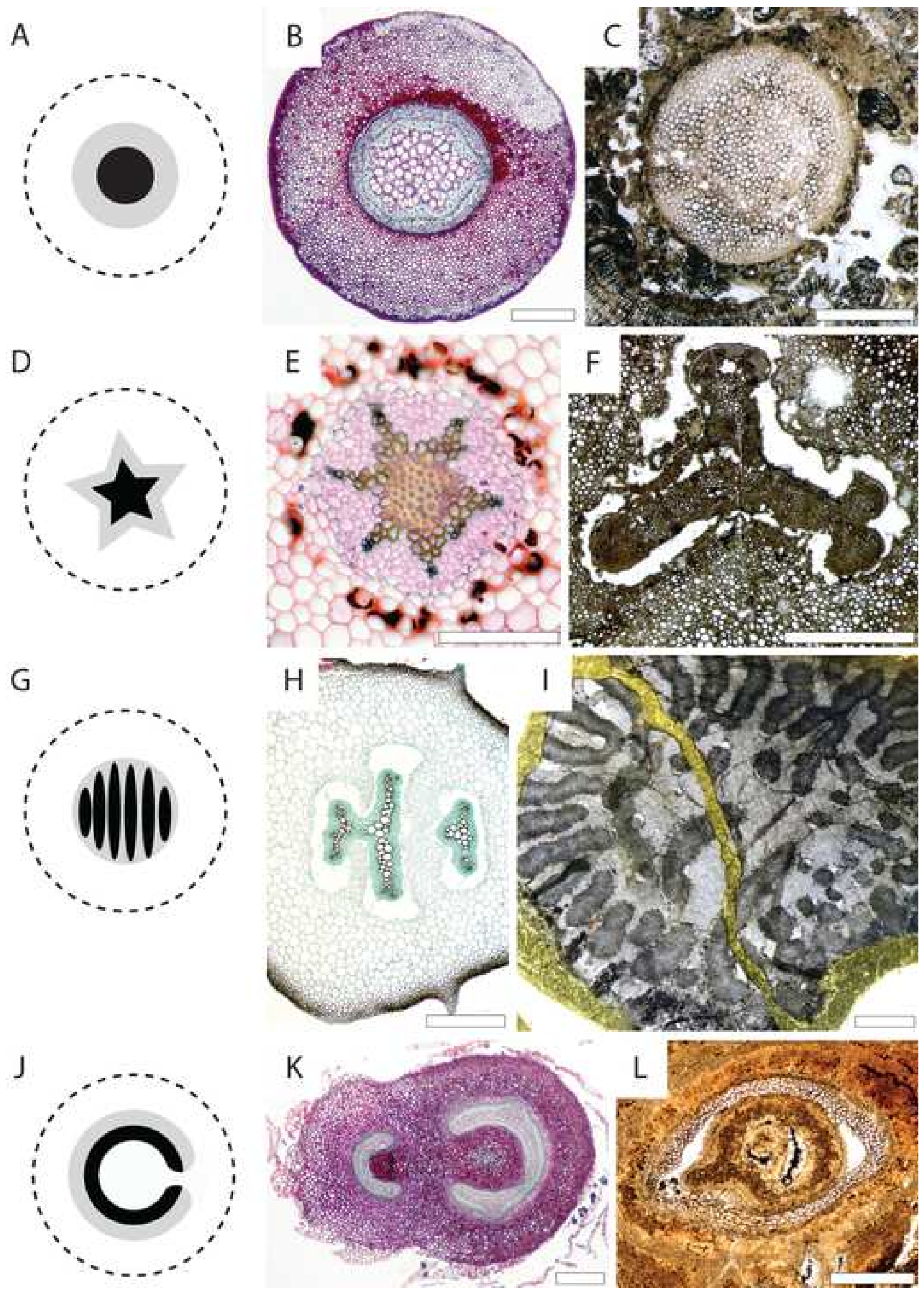
Click here to access/download;Figure;Fig 5 Stele diversity part 2.tif $\underline{\underline{ }}$
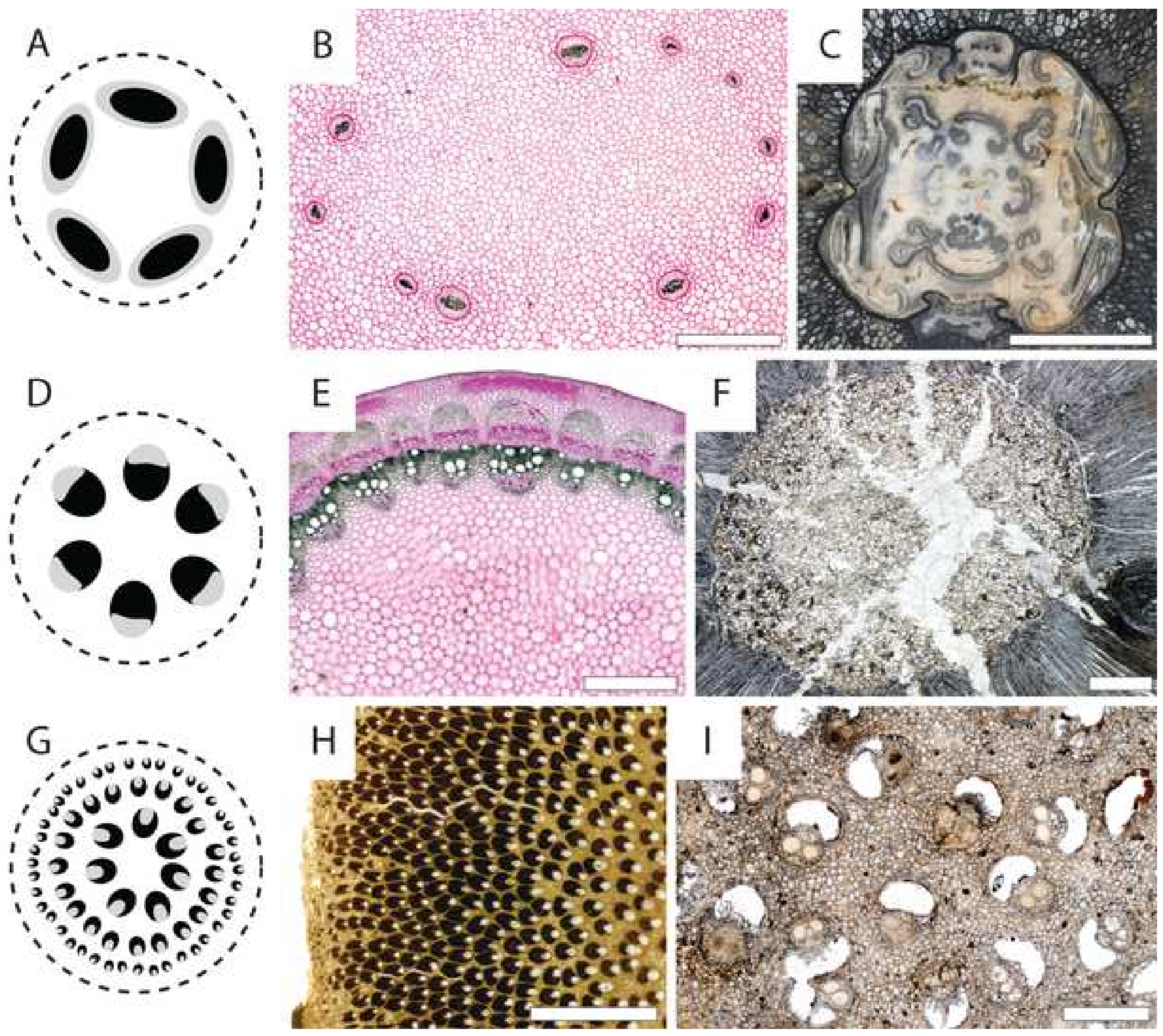

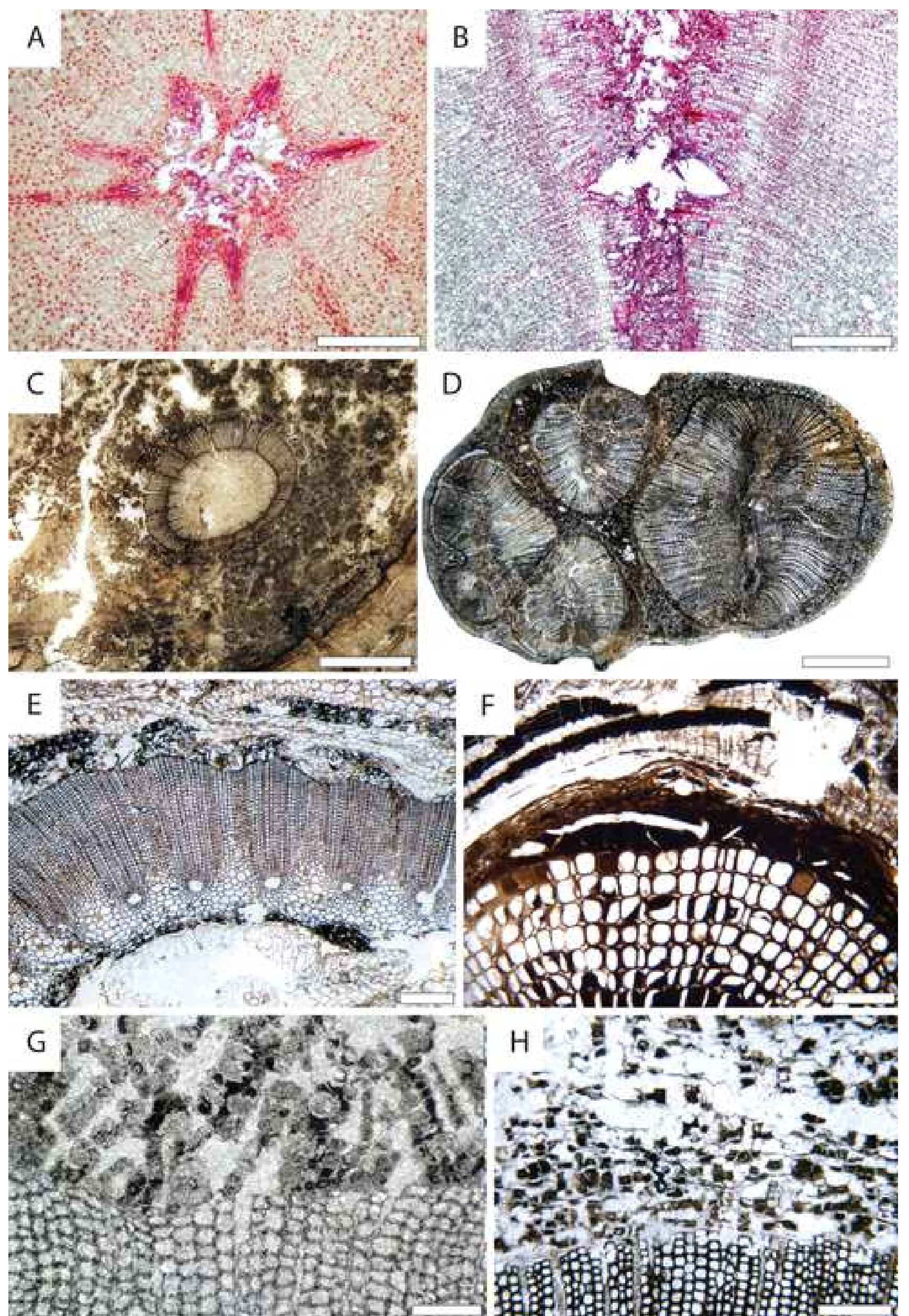

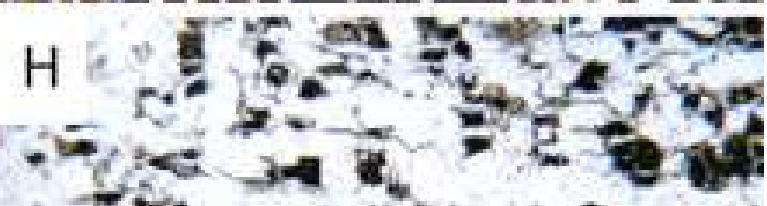

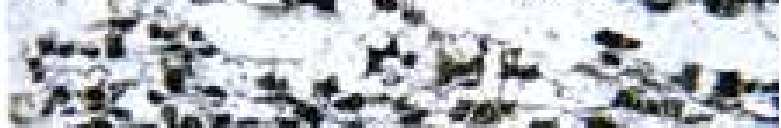

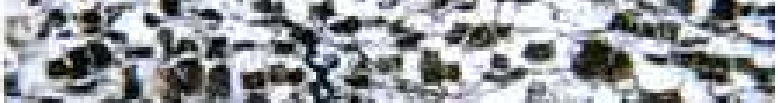

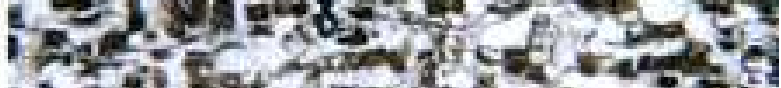

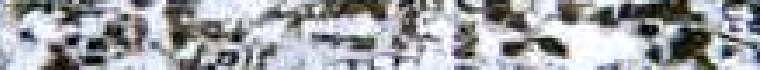
a. L 18 \%

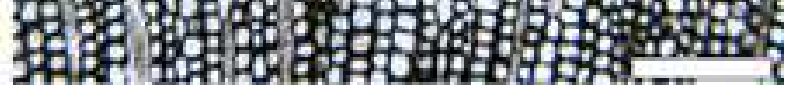



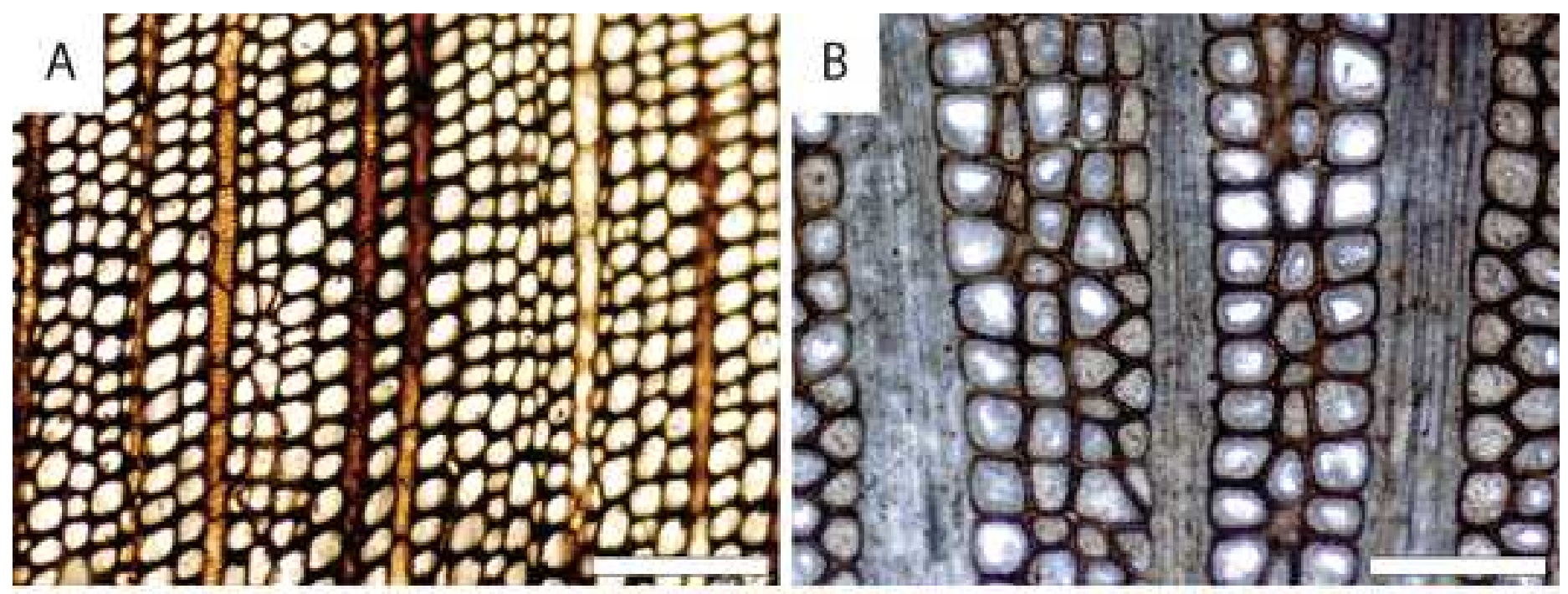

c FNO WWW
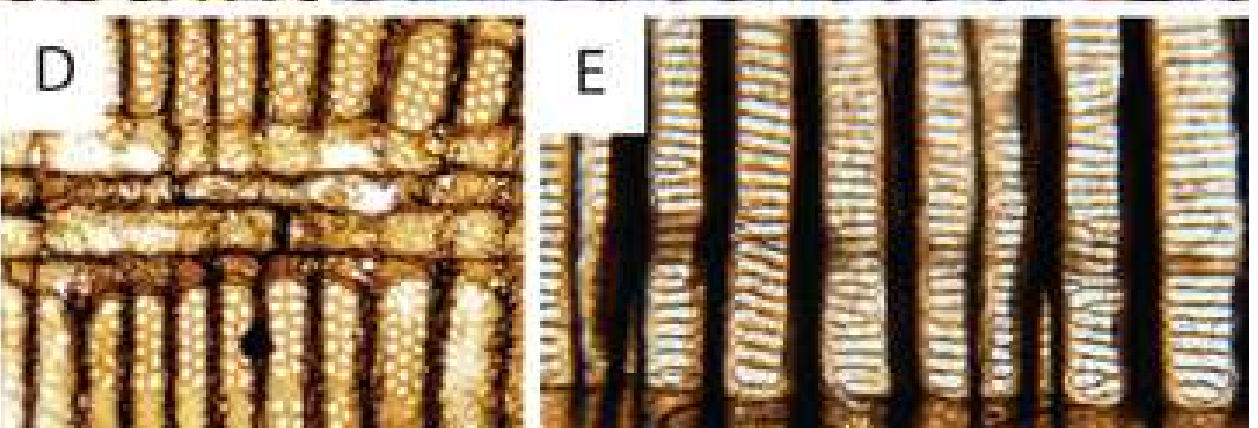

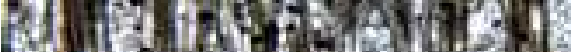

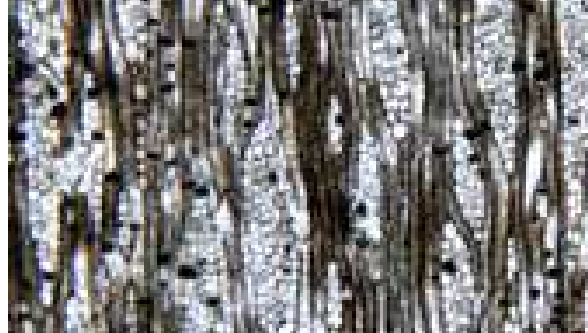

Sile

I. 3 .

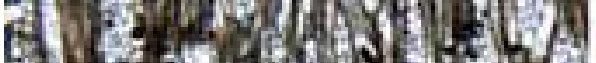

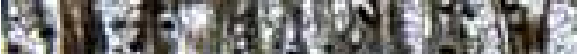
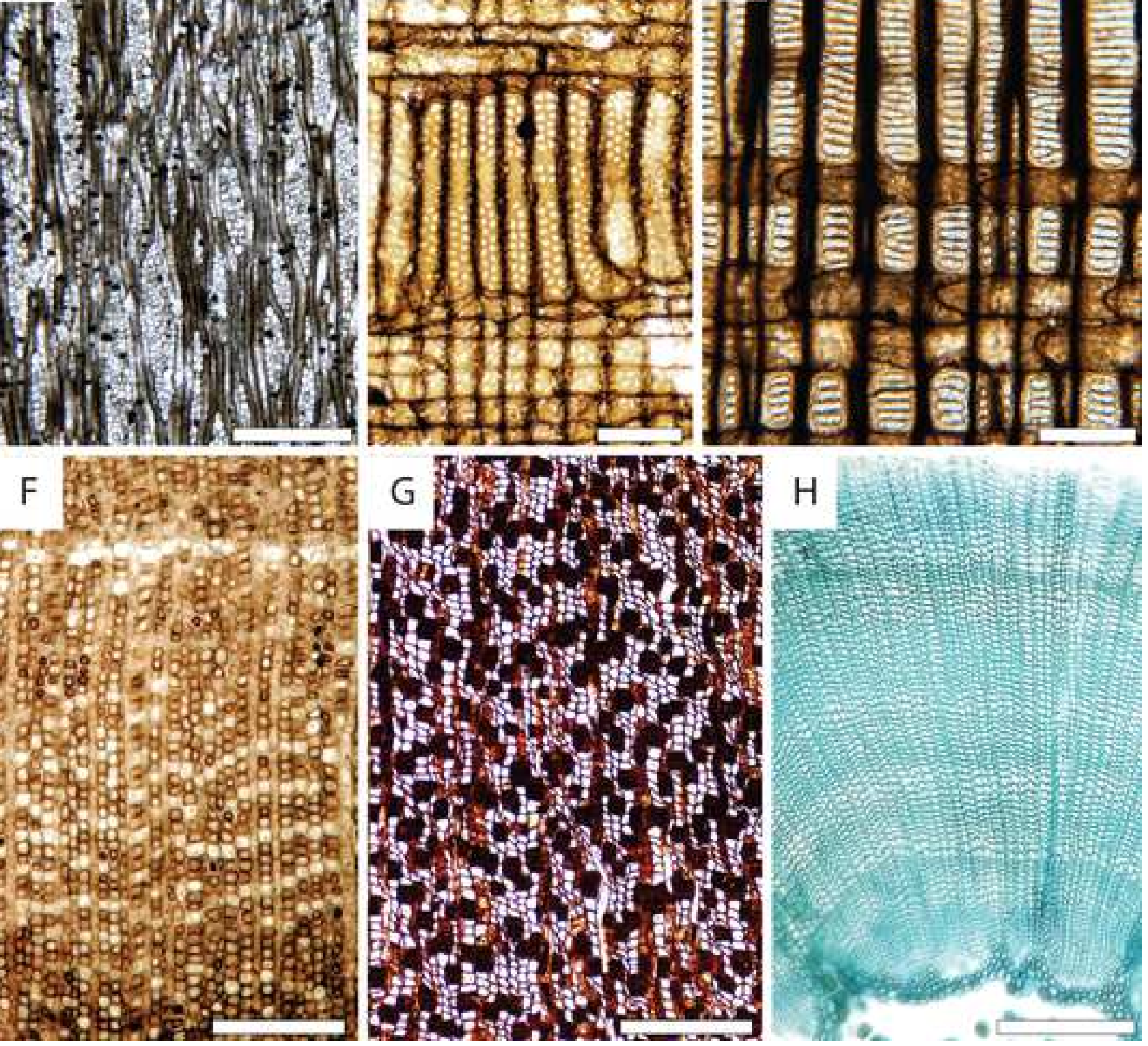

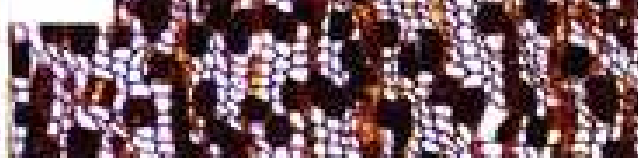

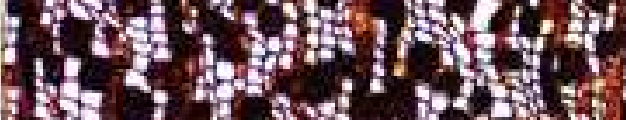

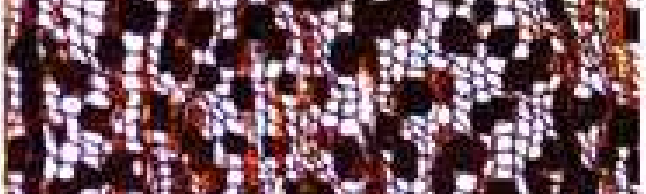

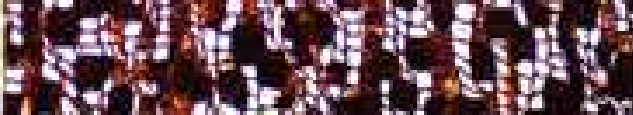

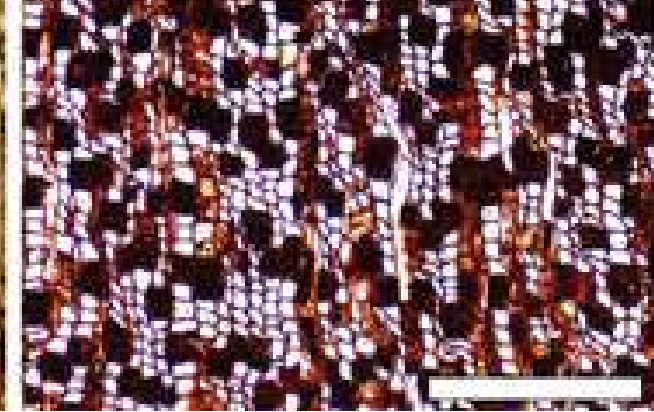



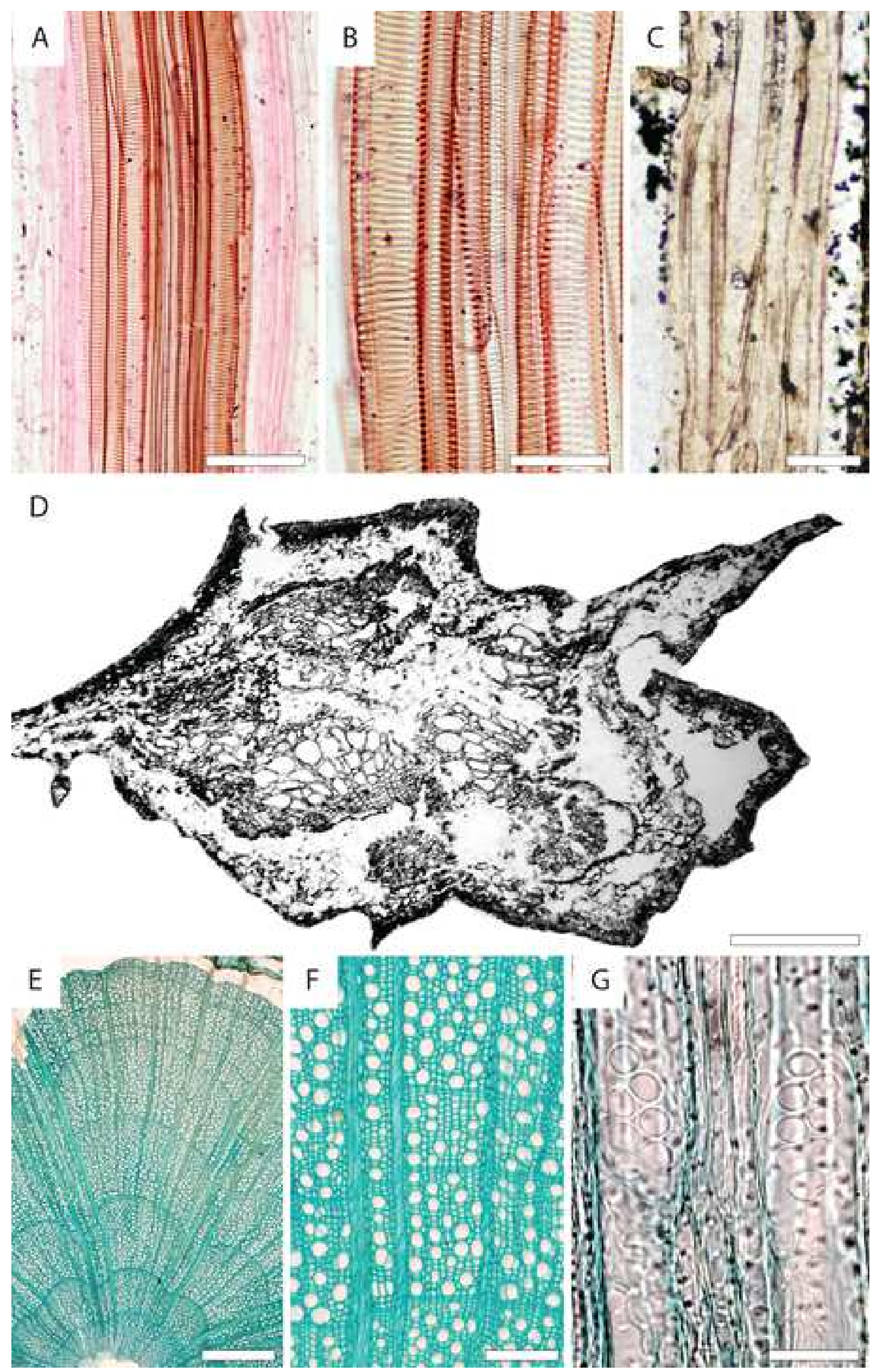